\title{
ИЗБИРАТЕЛИ \\ РАДИКАЛЬНЫХ ПРАВЫХ ПАРТИЙ В ЕВРОПЕ: \\ СОЦИАЛЬНАЯ ДЕМОГРАФИЯ, ПОЛИТИЧЕСКИЕ АТТИТЮДЫ, НАЦИОНАЛИЗМ
}

\section{В.В. Сафронов}

\author{
(vsafronov@list.ru) \\ Социологический институт РАН - филиал ФНИСЦ РАН, \\ Санкт-Петербург, Россия
}

Цитирование: Сафронов В.В. Избиратели радикальных правых партий в Европе: социальная демография, политические аттитюды, национализм // Власть и элиты. 2020. Т. 7, № 2. С. 22-63.

DOI: https://doi.org/10.31119/pe.2020.7.2.2

Аннотация. Обсуждаются отличительнье характеристики избирателей радикальных правых партий в странах Западной и Восточной Европы. Выявленные в многочисленных западных исследованиях зависимости ставятся сегодня под сомнение, и отмечаются приниипиальные расхождения между такими избирателями в одной и другой частях континента. Эмпирическая проверка этих утверждений осуществлялась с использованием данных Европейского социального исследования 20162017 г2. (ESS, Round 8) для четьрех западных стран (Австрия, Нидерланды, Финляндия и Франиия) и четырех восточных (Венгрия, Польша, Россия и Эстония). Результать позволяют подтвердить и уточнить сложившиеся научные представления об особенностях электората радикальных правых партий в странах Западной Европь. В нем диспропориионально представлены граждане с невысоким образованием и соииально-профессиональным статусом, младиие и средние возрастные когорты (представительство мужчин и женщин было сходным, хотя есть и исключения из этого правила). Главные отличия электората связаны с высокой неудовлетворенностью властями, работой политических структур и институтов и неприязненным отношением к иммигрантам и беженцам. В Восточной Европе голосующих за радикальные националистические партии также с большей вероятностью можно было встретить в младщих и средних возрастных группах (преобладание мужчин также не было общей закономерностью), однако ни образование, ни профессиональный статус существенной роли не играли. Для них тоже характерно недовольство политикой (в Польше - удовлетворенность, поскольку рассматриваемая 
партия выиграла выборь) и националистические взгляды, однако эти зависимости были не такими сильными, как в западных странах. Во всех странах (за единственным исключением) приверженность консервативным взглядам и иенностным ориентациям на безопасность, послушание, соблюдение традииий не относились к важным различительным переменным. Наименее отчетливыми были все отмеченные различия, исключая возрастные особенности, в России. Исследование показывает, что поддержка радикальных правых партий в Западной Европе соииально структурирована и отвечает их идеологическому предложению с характерным наиионалистическим уклоном и популистской риторикой. Такое предложение находит своих сторонников и в странах Восточной Европь, входящих в ЕС, однако их воззрения не соотносятся с социально-экономической стратификаиией общества.

Ключевье слова: радикальные правые партии, избиратели, сочиальная демография, политические аттитюдь, начионализм, Западная и Восточная Европа, Европейское социальное исследование 2016 (ESS Round 8).

\section{ПРОБЛЕМА И ЗАДАЧИ ИССЛЕДОВАНИЯ}

В последние годы во многих странах Западной и Восточной Европы стала особенно отчетливой тенденция, возникшая еще в начале 1980-х годов, которая свидетельствует о быстром росте электората и расширении парламентского представительства радикальных партий, идеологические ориентиры которых связаны с крайним национализмом [нативизмом], неприятием либеральной демократии и популизмом [Mudde 2007]. Согласно теоретическим представлением и эмпирическим фактам [Сафронов 2018; Rydgren 2018], в современных развитых индустриальных обществах эта тенденция порождается актуализацией радикальных националистических, консервативных и популистских взглядов в социальных стратах, проигравших вследствие постиндустриальной модернизации и процессов глобализации, а в Центральной и Восточной Европе - также в результате кардинальной трансформации прежних коммунистических общественных систем [Ignazi 1992; Bornschier 2018; Minkenberg 2015; Mudde 2016]. Мотивирующему воздействию взглядов на голосование за радикальных националистов способствуют и благоприятные политические возможности, возникающие, как считается, при пропорциональных избирательных системах и партийной конкуренции, организованной не в традиционном экономическом измерении, а по оси социально-культурного противостояния 
вокруг проблем окружающей среды, прав женщин, ЛГБТ, иммигрантов, беженцев [Kitschelt 2007; 2018].

Многочисленные исследования, нацеленные на выявление демографических и социальных особенностей избирателей правых радикалов, а также их аттитюдов и ценностей, позволили выделить ряд отличительных признаков (последние обзоры см. в: [Arzheimer 2018; Golder 2016; Muis, Immerzeel 2017]). Крайние правые партии склонны поддерживать представители рабочего и нижнего среднего классов, мелкого бизнеса. Это, как правило, избиратели с невысоким уровнем образования, скорее мужчины, чем женщины, и молодые, чем пожилые, люди, для их взглядов характерным является выраженное недовольство политикой [Arzheimer 2009; Arzheimer, Carter 2006; Coffé 2018; Lubbers, Gijsberts, Scheepers 2002; Norris 2005].

Но главное, что отличает тех, кто голосует за такие партии, - обеспокоенность угрозами обществу вследствие появления значительного числа иммигрантов из стран с отличной от Европы культурой [Arzheimer 2011; Ivarsflaten 2008; Lubbers, Gijsberts, Scheepers 2002; Oesch 2008; Rydgren 2008]. Она усиливает недоверие к политике основных парламентских партий, преследующих, как полагают эти избиратели, лишь свои узкие интересы, забыв о нуждах народа. Эти аттитюды позволяют в определенной степени объяснить классовые, профессиональные и образовательные различия в поддержке радикальных правых партий. Национальная идентификация, гордость и этническое понимание государственности, отражая другие аспекты национализма, также повышают вероятность голосования за эти партии [Lubbers, Coenders 2017]. Определенный вклад, помимо политического недоверия и этнической угрозы, вносит и евроскептицизм - недоверие структурам управления ЕС и представление о чрезмерном отказе от национального суверенитета [Werts, Scheepers, Lubbers 2013]. В странах Центральной и Восточной Европы популистские националистические партии тоже используют мобилизацию против этнических меньшинств, и если раньше это делалось по отношению к людям других национальностей, проживающих в стране, то в последнее время - против иммигрантов из неевропейских стран [Buštíková 2018].

Высокая поддержка радикальных правых партий в нижних общественных слоях порождается не только новыми экономическими угрозами и обострением проблем иммиграции, которые были вызваны глобализацией, но и неприятием изменений в культуре при переходе 
к постиндустриальному обществу. В обществе начинает складываться новое политическое противостояние, разделяющее образованные слои и социально-культурных специалистов из среднего класса, поддерживающих расширение свобод, терпимости, космополитизма, и промышленных и сервисных рабочих, клерков и владельцев малого бизнеса, выступающих сторонниками «консервативной контрреволюции» с позиций национализма и традиционных ценностей [Bornschier 2018; Ignazi 1992; Kitschelt 2007; Kriesi et al. 2008; 2012; Norris, Inglehart 2019; Oesch 2012]. Рост популистских партий, согласно данным Европейского социального исследования 20022014 гг., отражает реакцию консервативно настроенных слоев общества против широкого спектра быстрых культурных изменений, разъедающих традиционные ценности и установления [Inglehart, Norris 2016]. Либерализация в восточноевропейских демократиях отношения к этническим меньшинствам и усиление их политического влияния вызвали сходную ответную реакцию - рост голосов за популистские и националистические радикальные партии [Bustikova 2014].

Поддержка радикальных правых партий связана, таким образом, с менее образованными, нижними социальными слоями, питается политическим недовольством граждан, указывающим на недоверие к властям, лево- и правоцентристским парламентским партиям, структурам EC, значительно усиливается вследствие их тревоги, вызванной расширением иммиграционных потоков, и опирается на консервативные ценности. Хотя такие представления об электорате этих партий получили признание в научных кругах, есть работы, в которых они ставятся под сомнение. Согласно результатам анализа избирателей популистских партий в Западной Европе [Rooduijn 2018], даже если ограничиться только десятью представителями их радикального правого крыла, ни демография и социальная структура, ни евроскептицизм, а также, в меньшей мере, политическое недоверие не позволяют предложить общего объяснения электоральной поддержки для всех этих партий. Такое объяснение дает только одна переменная - аттитюды, поддерживающие запрет на иммиграцию. Метаанализ статей за последние двадцать с лишним лет, посвященных исследованию (с использованием регрессионного анализа) индивидуальных отличий избирателей, голосующих в Европе за радикальные правые партии, показал, что предполагаемые зависимости с любой из указанных характеристик, даже с антииммигрантскими аттитюдами, подтверждаются лишь менее чем в половине аналитических материалов [Stockemer, Lentz, Mayer 2018]. 
Усилению неопределенности способствуют недостаточная изученность проблемы в странах Центральной и Восточной Европы [Mudde 2017] и заметные отличия голосования за радикальных националистов в этих странах и в западных обществах - зависимости, характерные для последних, проявляются в них неотчетливо [Сафронов 2019; Kehrberg 2015]. В недавнем исследовании было показано, что разве только евроскептицизм объединяет избирателей радикальных правых партий по всей Европе, тогда как нативизм, выступающий на Западе самым сильным фактором, оказывал влияние лишь в отдельных странах Восточной Европы, а переменная политического недоверия была связана с таким голосованием обратной, чем в развитых европейских странах, зависимостью: избиратели этих партий были склонны доверять властям [Santana, Zagórski, Rama 2020].

В связи с отмеченными проблемами в настоящем исследовании предполагалось проверить, насколько обоснованными являются сомнения в закономерностях голосования за правых радикалов, выявленных в предшествующих работах, а также попытаться найти характерные особенности сторонников правых националистических партий в посткоммунистических обществах и установить, являются ли они специфичными для этого электората. В анализ включались несколько стран Западной и Восточной Европы, в которых правые радикальные партии получали на недавних общенациональных парламентских выборах заметную поддержку. Он был нацелен на решение четырех основных задач. Первая предполагала выявление характерных признаков социальной демографии современных избирателей радикальных правых партий в тех и других странах. Вторая задача - описание их политических аттитюдов, включая отношение к властям, политическим институтам и демократической системе соответствующих государств, а также к Европейскому парламенту и процессу европейской интеграции. Третья была связана с проверкой предположений о мотивации этих избирателей недовольством, вызванным ростом в странах Европы численности иммигрантов и беженцев из слаборазвитых стран с чуждой европейцам культурой. Наконец, четвертая задача - поиск ценностных оснований этой мотивации, опираясь на соображения о вероятной приверженности голосующих ориентациям на безопасность, подчинение и усиление государства, а также на сохранение традиций и консервативных норм, в том числе в области гендерных отношений, семьи и сексуального поведения. 


\section{ЭМПИРИЧЕСКИЕ ДАННЫЕ И МЕТОДЫ АНАЛИЗА}

В настоящей работе анализировались данные репрезентативных национальных опросов Европейского социального исследования (последние из доступных массивов, включающих все участвовавшие страны [ESS Round 8... 2016]). Для углубленного рассмотрения были отобраны по четыре страны Западной и Восточной Европы, в которых радикальным правым партиям удалось получить заметное число голосов на последних перед опросами общенациональных парламентских выборах. Названия этих партий и полученные ими голоса на выборах, о которых спрашивали респондентов во время ESS опросов в 2016 г., представлены в таблице 1.

Таблица 1

Включенные в анализ страны, парламентские выборы и радикальные партии

\begin{tabular}{|c|c|c|c|}
\hline Страны & $\begin{array}{c}\text { Радикальные } \\
\text { правые партии }\end{array}$ & $\begin{array}{c}\text { Год } \\
\text { выборов }\end{array}$ & $\begin{array}{c}\text { Голоса, } \\
\% \\
\end{array}$ \\
\hline \multicolumn{4}{|c|}{ ЗАПАДНАЯ ЕВРОПА } \\
\hline \multirow{2}{*}{ Австрия } & $\begin{array}{c}\text { Австрийская партия } \\
\text { свободы, FРӦ }\end{array}$ & 2013 & 20.5 \\
\hline & $\begin{array}{c}\text { Альянс за будущее Австрии, } \\
\text { ВZÖ } \\
\end{array}$ & & 3.5 \\
\hline Нидерланды & Партия свободы, PVV & 2012 & 10.1 \\
\hline Финляндия & Истинные финны, PS & 2015 & 17.6 \\
\hline Франция & Национальный фронт, FN & 2012 & 13.6 \\
\hline \multicolumn{4}{|c|}{ ВОСТОЧНАЯ ЕВРОПА } \\
\hline Венгрия & Йоббик, Jobbik & 2014 & 20.2 \\
\hline Польша & Право и справедливость, PiS & 2015 & 37.6 \\
\hline \multirow{2}{*}{ Россия } & ЛДПР & 2016 & 13.1 \\
\hline & Родина & & 1.5 \\
\hline Эстония & $\begin{array}{c}\text { Консервативная народная } \\
\text { партия Эстонии, EKRE }\end{array}$ & 2015 & 8.0 \\
\hline
\end{tabular}

При проведении анализа учитывались только те респонденты, которые во время интервью сообщили, что принимали участие в последних общенациональных парламентских выборах (нижних палат - при двухпалатной системе). В каждой из стран, опираясь на статистический анализ таблиц сопряженности, парных корреляций и логистических регрессий, изучался широкий спектр индивидуальных переменных в их 
связи с голосованием за соответствующую партию. Эти переменные составляют четыре блока характеристик:

(1) СОЦИАЛЬНАЯ ДЕМОГРАФИЯ

Пол: 0 - женщины, 1 - мужчины.

Возраст - в годах, а также представленный шестью категориями: 1 - до 25 лет; 2 - 25-34 года; 3 - 35-44 года; 4 - 45-54 года; 5 55-64 года; 6 - 65 лет и старше.

Образование - Международная стандартная классификация образования (версия ISCED, International Standard Classification of Education, разработанная для Европейского социального исследования, см.: [ESS8... 2016]), включающая семь категорий: 1 - ниже неполного среднего; 2 - неполное среднее; 3 - среднее, нижний уровень; 4 среднее, верхний уровень; 5 - продвинутое профессиональное; 6 высшее, нижний уровень, степень бакалавра; 7 - высшее, верхний уровень, степень магистра и выше (1 - ES-ISCED I, less than lower secondary; 2 - ES-ISCED II, lower secondary; 3 - ES-ISCED IIIb, lower tier upper secondary; 4 - ES-ISCED IIIa, upper tier upper secondary; 5 ES-ISCED IV, advanced vocational, sub-degree; 6 - ES-ISCED V1, lower tertiary education, BA level; 7 - ES-ISCED V2, higher tertiary education, $>=$ MA level).

Место жительства - по описанию участников опросов: 1 - крупный город; 2 - пригороды крупного города; 3 - небольшой город; 4 - село, деревня; 5 - ферма, дом в сельской местности.

Профессиональный статус - Международная стандартная классификация профессий (International Standard Classification of Occupations, ISCO 08, см.: [International Labour Office 2012]), включающая девять обобщающих категорий: 1 - руководители, менеджеры; 2 - профессионалы; 3 - специалисты-техники; 4 - клерки, офисные работники; 5 - работники сферы услуг и торговли; 6 - квалифицированные рабочие в сельском хозяйстве, лесной и рыбной отраслях; 7 - рабочие квалифицированного ручного труда; 8 - операторы машин, сборочных линий; 9 - простейшие, неквалифицированные профессии.

Воспринимаемыцй уровень жизни - шкала ответов на вопрос анкеты «Какое из высказываний на этой карточке наиболее точно описывает уровень дохода вашей семьи в настоящее время?»: 1 - «Живем на этот доход, не испытывая материальных затруднений»; 2 - «Этого дохода нам в принципе хватает»; 3 - «Жить на такой доход довольно трудно»; 4 - «Жить на такой доход очень трудно». 
Религиозность - указание «насколько религиозным человеком вы себя считаете?» по шкале от 0 - совсем не религиозным до 10 - очень религиозным.

(2) ПОЛИТИЧЕСКИЕ АТТИТЮДЫ

Неудовлетворенность руководством страны - «...тем, как оно выполняет свою работу?» по шкале от 0 - совершенно не удовлетворен до 10 - полностью удовлетворен.

Политическое недоверие - оценки, выставленные отдельно политикам, политическим партиям и национальному парламенту по шкале от 0 - совершенно не доверяю до 10 - полностью доверяю, преобразуются (поскольку достаточно тесно взаимосвязаны) в обобщающий индекс (среднее арифметическое значение для трех отдельных шкал).

Невосприимчивость политической системь к интересам граждан - среднее арифметическое оценок при ответах на два вопроса: «В какой мере... нынешняя политическая система в (стране) позволяет таким людям, как вы, сказать свое слово в решении о том, в каком направлении действовать правительству?» и «...влиять на политику?» (шкалы от 1 - совсем нет до 5 - очень много).

Неудовлетворенность демократией - «Если говорить в целом, насколько вы удовлетворены тем, как работает демократия в (стране)?», шкала от 0 - совершенно не удовлетворен до 10 - полностью удовлетворен.

Недоверие Европейскому парламенту - по шкале от 0 - совершенно не доверяю до 10 - полностью доверяю.

(3) НАЦИОНАЛИСТИЧЕСКИЕ ВЗГЛЯДЫ

Убеждения об общественных последствиях иммиграиии - измерялись с помощью трех вопросов: «Как вы считаете, то, что люди из других стран переезжают в (нашу страну), в целом плохо или хорошо сказывается на экономике (страны)?» (шкала 0 - плохо для экономики, 10 - хорошо для экономики), «...приток людей из других стран скорее разрушает или скорее обогащает культуру (страны)?» (шкала 0 - разрушает культуру нашей страны, 10 - обогащает культуру нашей страны) и «...с притоком людей из других стран (наша страна) как место для жизни становится лучше или хуже?» (шкала 0 - становится хуже, 10 - лучше). Рассчитывался индекс (среднее арифметическое значение), отражающий позиции респондента по этим трем шкалам.

Aттитюдь к бежениам - оценивались по индексу (среднее арифметическое значение), отражающему степень согласия опрошенных 
(шкала от $1-$ полностью согласен до $5-$ совершенно не согласен) со следующими суждениями: «Правительство должно без особых придирок предоставлять людям статус беженцев», «Большинство просящих статус беженца на самом деле совсем не боятся никаких преследований в своих странах» и «Людям, которые получили статус беженца, должно быть разрешено перевезти также близких членов своей семьи».

Отношение к объединению Европь - «Некоторые люди говорят, что процесс объединения Европы должен продолжаться. Другие считают, что объединение и так уже зашло слишком далеко», позиция на шкале между этими полюсами от 0 до 10.

(4) ЦЕННОСТНЫЕ ПРЕДПОЧТЕНИЯ И КОНСЕРВАТИВНЫЕ ВЗГЛЯДЫ

Ценностные ориентации - в ESS используется Портретный ценностный вопросник (21-item Portrait Values Questionnaire, PVQ, Schwartz 2001), содержащий 21 суждение с описанием людей, которых респондент оценивает по степени похожести на себя (шкала от 1 - очень похож на меня до 6 - совсем на меня не похож). Позволяет описать десять типов предпочтений, выделяемых в теории ценностных универсалий Ш. Шварца [Schwartz 1992; 2012], включая ориентации на «безопасность», «конформизм» и «традиции», близкие авторитарно-консервативным аспектам идеологии радикальных правых (значимость для респондента каждой из ценностей рассчитывается относительно его средней оценки по шкалам всех суждений).

Консервативные гендерные и семейные стереотипы - степень согласия (по шкале от 1 - полностью согласен до 5 - совершенно не согласен) с суждениями: «Когда рабочих мест не хватает, у мужчин должно быть преимущество перед женщинами при приеме на работу» и «Однополые пары должны иметь такие же права усыновлять детей, как и традиционные семейные пары».

\section{ЭЛЕКТОРАТ РАДИКАЛЬНЫХ ПРАВЫХ ПАРТИЙ: СОЦИАЛЬНАЯ ДЕМОГРАФИЯ}

Влияние на голосование за радикальные националистические партии переменных, характеризующих социальную демографию опрошенных, анализировалось с помощью логистических регрессий. Результаты этого анализа для стран Западной Европы сведены в таблицу 2. 


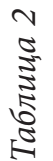

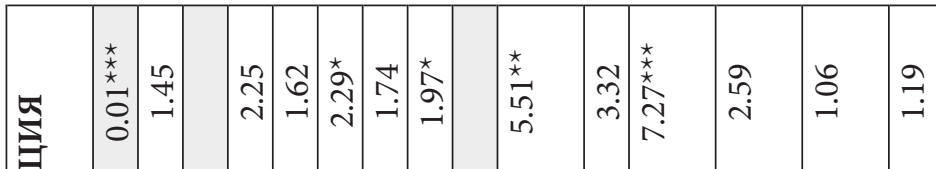

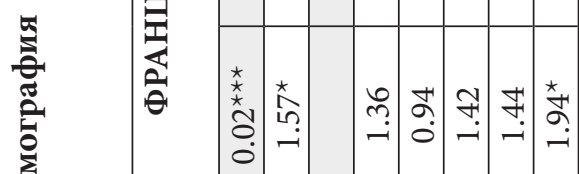

过

8

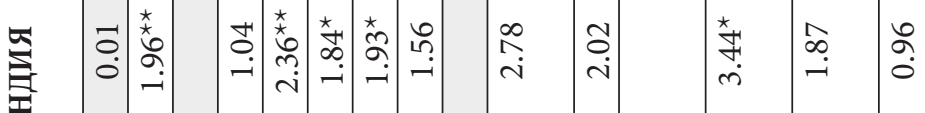

苛 㿣

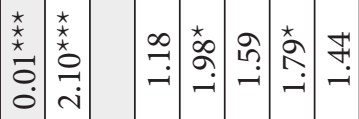

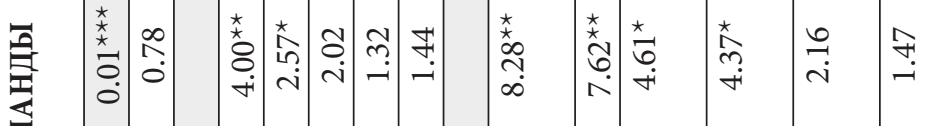

กี

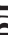

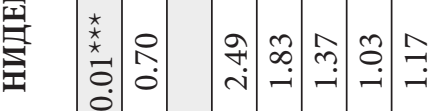

.

ํㅜㄹ

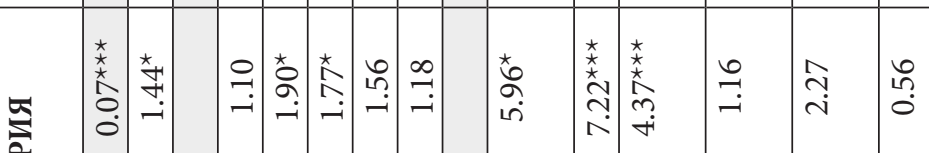

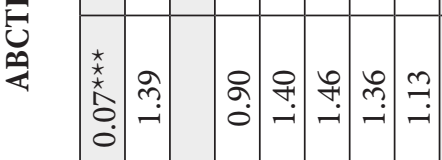

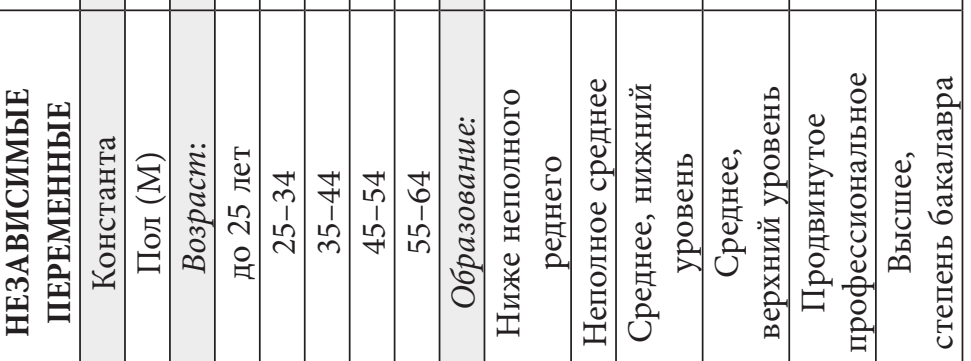




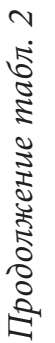

\begin{tabular}{|c|c|c|c|c|c|c|c|c|c|c|c|c|c|c|}
\hline \multirow{2}{*}{ 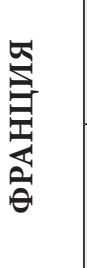 } & & $\stackrel{\sim}{n}$ & $\stackrel{\infty}{\stackrel{\infty}{\sim}}$ & $\stackrel{\circ}{\infty}$ & 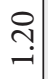 & & $\tilde{n}$ & 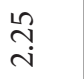 & $\stackrel{n}{\sim}$ & $\begin{array}{l}\overline{0} \\
\dot{1}\end{array}$ & $\stackrel{\overbrace{}}{\sim}$ & $\stackrel{尺}{\Re}$ & $\stackrel{\square}{\stackrel{4}{\sim}}$ & $\stackrel{\text { ঙ }}{\sim}$ \\
\hline & & & ñ & 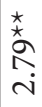 & $\stackrel{n}{\sigma}$ & & $\frac{10}{2}$ & 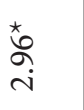 & $\stackrel{+}{\stackrel{2}{\digamma}}$ & ले & 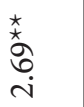 & $\begin{array}{l}0 \\
\stackrel{2}{r}\end{array}$ & ๗ે & $\stackrel{0}{ت}$ \\
\hline \multirow{2}{*}{ 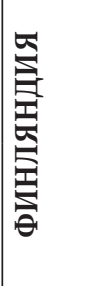 } & & $\tilde{\sigma}$ & $\stackrel{\text { L }}{\stackrel{f}{\longrightarrow}}$ & $\stackrel{\overbrace{}}{\text { ำ }}$ & $\underset{+}{\stackrel{9}{+}}$ & & 吕 & $\begin{array}{l}\stackrel{\star}{\star} \\
\stackrel{\star}{\sim} \\
\stackrel{n}{m}\end{array}$ & 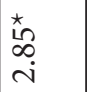 & $\widetilde{\Sigma}$ & \begin{tabular}{l}
\multirow{L}{*}{} \\
$\stackrel{2}{n}$ \\
in
\end{tabular} & $\vec{\sigma}$ & $\mid \begin{array}{l}\infty \\
\infty \\
\infty \\
-1\end{array}$ & $\hat{\sigma}$ \\
\hline & & ప્م & in & خิ & $\widehat{\sigma}$ & & 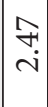 & 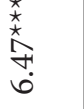 & 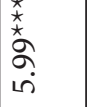 & $\stackrel{\sim}{n}$ & $\begin{array}{l}\stackrel{\star}{\star} \\
\stackrel{\star}{\star} \\
\stackrel{\infty}{\infty} \\
\dot{+} \\
\dot{+}\end{array}$ & 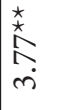 & 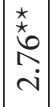 & ๙ু \\
\hline \multirow{2}{*}{ 煦 } & & $\begin{array}{l}\text { 衤 } \\
\text { in } \\
\text { N }\end{array}$ & $\stackrel{\star x}{\sim}$ & $\stackrel{n}{n}$ & $\stackrel{1}{0}$ & & నू & 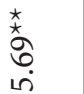 & $\stackrel{\text { a }}{\text { s. }}$ & ○े & م & $\stackrel{+}{\infty}$ & $\mid \begin{array}{l}1 \\
\infty \\
\infty \\
0\end{array}$ & $\stackrel{\infty}{\stackrel{\infty}{\sim}}$ \\
\hline & & 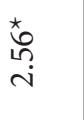 & 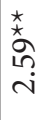 & กْ & $\overrightarrow{\widetilde{o}}$ & & 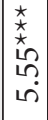 & 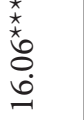 & $\begin{array}{l}\stackrel{x}{x} \\
\stackrel{x}{\star} \\
\stackrel{+}{+} \\
\infty \\
\infty\end{array}$ & ○ & 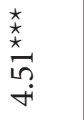 & 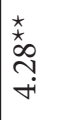 & $\mid \begin{array}{l}0 \\
0 \\
\end{array}$ & $\stackrel{\circ}{\Re}$ \\
\hline \multirow{2}{*}{ 冚 } & & $\begin{array}{l}\stackrel{\star}{\star} \\
\stackrel{\infty}{\sim} \\
\stackrel{\sim}{v} \\
\sim\end{array}$ & ב & $\bar{\sigma}$ & $\begin{array}{l}\hat{b} \\
\dot{0}\end{array}$ & & $\begin{array}{l}10 \\
0 \\
0\end{array}$ & $\stackrel{\star}{\overbrace{}^{*}}$ & $\stackrel{\text { In }}{\circ}$ & 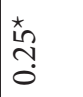 & & 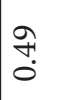 & $\mid \begin{array}{l}x \\
\infty \\
\infty \\
0 \\
0\end{array}$ & $\vec{\sigma}$ \\
\hline & & 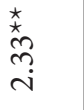 & $\stackrel{n}{n}$ & $\stackrel{\sim}{\sim}$ & $\begin{array}{l}\stackrel{2}{\widehat{0}} \\
\stackrel{0}{2}\end{array}$ & & 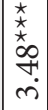 & $\underset{\sim}{\vec{H}}$ & $\stackrel{\infty}{\infty}$ & & 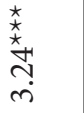 & 只 & $\begin{array}{l}2 \\
\hat{0}\end{array}$ & חָ \\
\hline 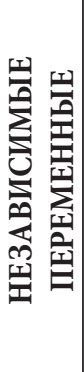 & 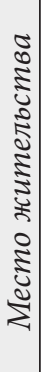 & 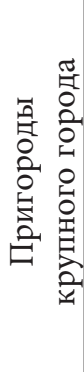 & 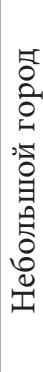 & 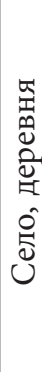 & 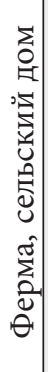 & 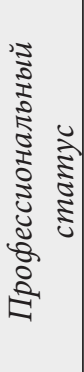 & 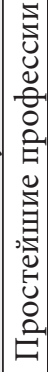 & 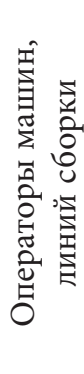 & 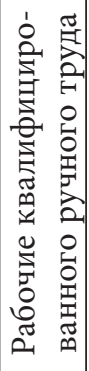 & 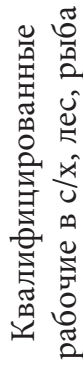 & 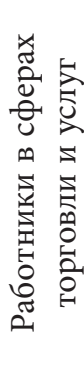 & 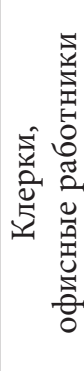 & 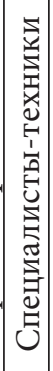 & 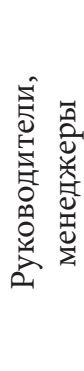 \\
\hline
\end{tabular}




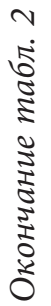

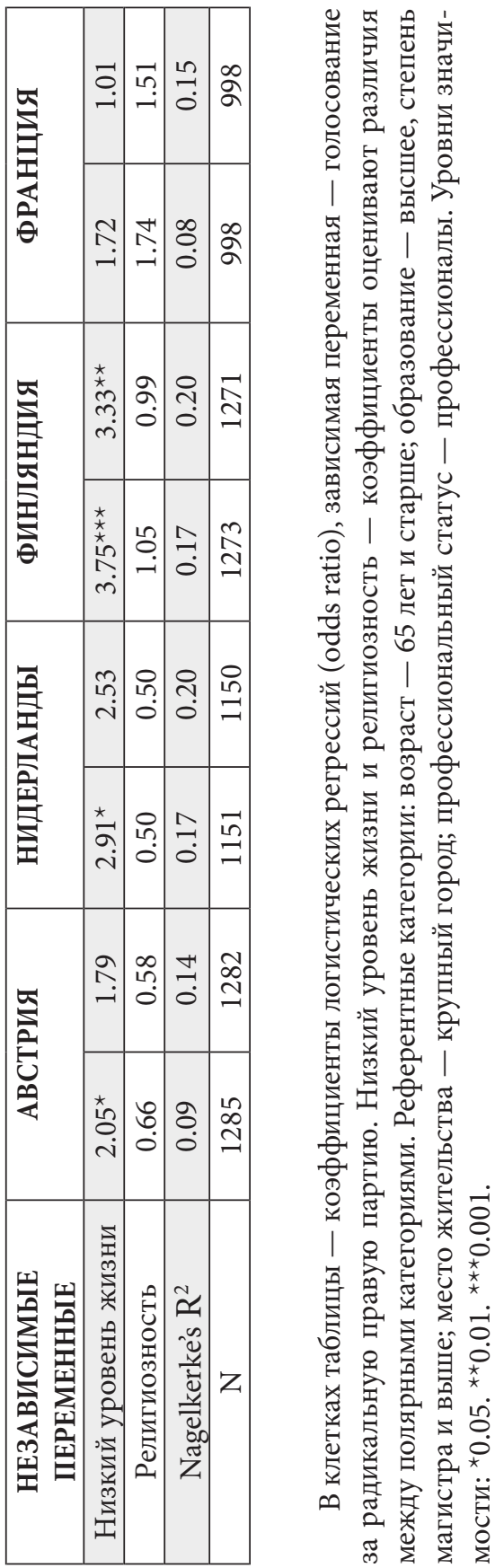


Для каждой из них приводятся две модели - в первой набор независимых переменных включает показатели пола, возраста, места жительства, профессионального статуса и оценки уровня жизни и религиозности, а во второй он дополнен признаком образования (это позволяет оценить самостоятельное влияние обоих связанных между собой факторов социально-экономического статуса - профессионального положения и уровня образования индивида).

В Австрии, согласно первой модели, можно обнаружить отчетливые различия избирателей Австрийской партии свободы (FPÖ) и Альянса за будущее Австрии (BZÖ) по профессиональному статусу. По сравнению с референтной категорией «профессионалы», представители которой менее всего склонны голосовать за эти партии, их избирателей с гораздо большей вероятностью можно встретить среди рабочих, занятых простейшим, неквалифицированным трудом, а также работников в сферах торговли и услуг.

Важную различительную роль, как показывает вторая модель, играет и образование - объяснительные возможности модели заметно повышаются, о чем свидетельствует увеличение Nagelkerke’s $\mathrm{R}^{2}$ с 0.09 до 0.14. Респонденты, имеющие степень не ниже магистра или соизмеримое образование, наименее склонны отдавать свои голоса радикальным правым партиям, тогда как люди с невысоким образовательным уровнем (ниже неполного среднего, с неполным средним и средним нижнего уровня) это делают, напротив, чаще других. Коэффициенты для профессионального статуса при этом меняют знак (odds ratio становятся меньше единицы) и утрачивают по большей части статистическую значимость, что происходит вследствие тесных взаимосвязей двух показателей социально-экономического статуса. Различия, обусловленные профессиональным статусом, в определенной мере объясняются тем, что работники, занятые менее квалифицированным трудом, имеют, как правило, невысокое образование, а те, кто занимает высокие позиции в профессиональной структуре, получают его в высших учебных заведениях. Среди показателей социальной демографии самые отчетливые дифференциации связаны с описанными социально-структурными особенностями, но следует также отметить, что за FPÖ (BZÖ) скорее голосуют в пригородах, чем в крупных городах, а также люди, испытывающие материальные трудности из-за недостаточных доходов. Мужчины, как и предполагалось, чаще, чем женщины, отдают свои голоса этим партиям, однако такая зависимость оказалась очень слабой. 
За них скорее голосуют люди младшего-среднего возраста (25-34 и 35-44 года), но не представители самой младшей когорты (до 25 лет), правда, эти различия вновь были весьма слабыми. Интересующие нас избиратели не считают себя религиозными людьми, хотя такая зависимость оставалась вне принятых критериев статистической значимости.

В Нидерландах обнаруживаются сходные закономерности структурирования голосования за Партию свободы (PVV), причем они выражены даже с большей определенностью, чем в австрийской выборке. Особенно много голосующих за эту партию было среди квалифицированных рабочих, но с большей вероятностью их можно встретить также в рядах неквалифицированных рабочих, работников торговли и сферы услуг, клерков, в отличие от профессионалов, не склонных ее поддерживать. Коэффициенты, характеризующие профессиональные особенности, существенно уменьшаются после контроля образования, при этом полная модель немного лучше объясняет электоральное поведение - Nagelkerke's $R^{2}$ повышается с 0.17 до 0.20. Это происходит потому, что избиратели PVV чаще встречаются среди респондентов с невысоким образовательным уровнем, которые и в профессиональной стратификации занимают невысокие позиции. Эти избиратели, кроме того, проживают скорее в небольших городах и пригородной зоне больших городов, принадлежат к младшим возрастным когортам и испытывают материальную депривацию. Пол и религиозность существенной роли не играют.

В Финляндии, как видно в таблице 2, электорат партии «Истинные финны» (PS) диспропорционально представлен квалифицированными рабочими и работниками торговли и предоставления услуг, но заметна и существенная разница между профессионалами, наименее склонными к ее поддержке, и простыми офисными работниками и специалистами-техниками. Включение в регрессию образования приводит к улучшению ее объяснительных возможностей - $\mathrm{R}^{2}$ изменяется с 0.17 до 0.20, что говорит о важности этой переменной, однако соответствующие ей коэффициенты оказываются статистически незначимыми, а коэффициенты для профессионального статуса отчетливо уменьшаются. Такой эффект вызван, как уже отмечалось, тесными взаимосвязями показателей профессии и образования, и он не означает их слабой дифференцирующей силы. Избиратели PS, кроме того, это скорее мужчины, чем женщины, по возрастному делению относятся к младшим-средним категориям (25-34 года, но также 35-44 и 45-54 года). Они испытывают 
материальные затруднения из-за низких доходов. Место жительства и религиозность при контроле прочих переменных особого значения не имеют.

Национальный фронт (FN) во Франции имеет бо́льшую популярность среди работников, занимающих невысокие позиции в профессиональной структуре, прежде всего в рядах рабочих-операторов машин и линий сборки, работников торговли и сферы услуг, представителей наименее квалифицированных профессий, тогда как профессионалы проявляют наименьшую склонность голосовать за эту партию. Эти различия, однако, не очень отчетливы, и при добавлении в число независимых переменных образования существенно сокращаются и утрачивают статистическую значимость. Модель, учитывающая структурирование по образованию, заметно лучше объясняет электоральное поведение $-\mathrm{R}^{2}$ увеличивается с 0.08 до 0.15. За FN с большей вероятностью голосуют люди с невысоким образованием - средним нижнего уровня, неполным средним и ниже, тогда как наиболее образованные респонденты к этому были не склонны. Ее сторонники - это скорее сельские жители, однако во второй модели такие различия оказываются неважными. То же самое можно сказать и о влиянии пола - слабые отличия, свидетельствующие о преобладании мужчин, после контроля образования становятся незначимыми в статистическом смысле. Возрастные особенности избирателей тоже выражены неотчетливо - коэффициенты немного выше в самой младшей группе и категории 3544 года (но и 55-64), чем в категории пожилых людей. Влияние показателей религиозности и уровня жизни было слабым.

Результаты исследования социальной демографии в странах Западной Европы подтверждают выявленный в предшествующих работах синдром характеристик, отличающих избирателей радикальных правых националистических партий, правда, с некоторыми уточнениями. Достаточно отчетливо проявляются демографические и социально-структурные особенности, указывающие на большую склонность к голосованию за эти партии избирателей младших и средних возрастов, она существенно выше у менее образованных людей, но необязательно у тех, кто имеет самое низкое - только начальное - образование, а также у респондентов с невысоким профессиональным статусом, среди которых могут оказаться неквалифицированные и квалифицированные рабочие, работники торговли и сферы услуг, а в некоторых странах и офисные работники с рутинными функциями. Вопреки некоторым прежним 
свидетельствам наш анализ не согласуется с предположениями о более вероятном голосовании за радикалов правого толка мужчин, чем женщин: только в Финляндии можно указать на эту зависимость, тогда как в других странах она была неотчетливой. К поддержке этих радикалов могут подтолкнуть и тяготы жизни, вызванные низкими доходами. Меньше голосуют за них в крупных городах, а больше - в их пригородах или небольших городах, но это отмечается только в двух из изучавшихся стран. Таким образом, наш анализ показывает, что самые сильные в Западной Европы факторы электоральной поддержки радикальных правых партий связаны с положением индивидов в социальной структуре - их профессиональным статусом и образованием.

Аналогичные регрессионные модели для стран Восточной Европы представлены в таблице 3. Они имеют ряд особенностей, отличающих их от описанных зависимостей в западных странах.

При рассмотрении кросс-табуляций, описывающих голосование в Венгрии за партию «Йоббик» по каждой из наших независимых переменных, выяснилось, что это с большей вероятностью делают мужчины, представители младших-средних возрастных когорт, респонденты со средним-высоким образованием, люди, не считающие себя религиозными. Существенных различий по профессиональному статусу, месту жительства и оценкам уровня жизни не оказалось. Модели, приведенные в таблице 3, уточняют эти дифференциации - некоторые из них были достаточно слабыми и теряют статистическую значимость при взаимном контроле независимых переменных (в регрессиях треть респондентов попадает в категорию «missing data», прежде всего вследствие отсутствия у них сведений о профессии).

Согласно коэффициентам во второй модели (с образованием), больше сторонников этой партии было среди неквалифицированных и квалифицированных рабочих, по месту жительства выделяется категория «ферма, дом в сельской местности», по образованию - те, у кого оно продвинутого профессионального уровня, дает степень бакалавра или соответствует полному среднему. Однако вследствие отмеченного сокращения выборки нельзя с уверенностью утверждать о существовании таких дифференциаций: все перечисленные коэффициенты оставались за пределами статистической значимости. Тем не менее указанные характеристики образования нельзя не учитывать, о чем свидетельствует заметное улучшение объяснительного потенциала регрессии при учете этой переменной - происходит увеличение $\mathrm{R}^{2}$ c 0.14 до 0.17. 


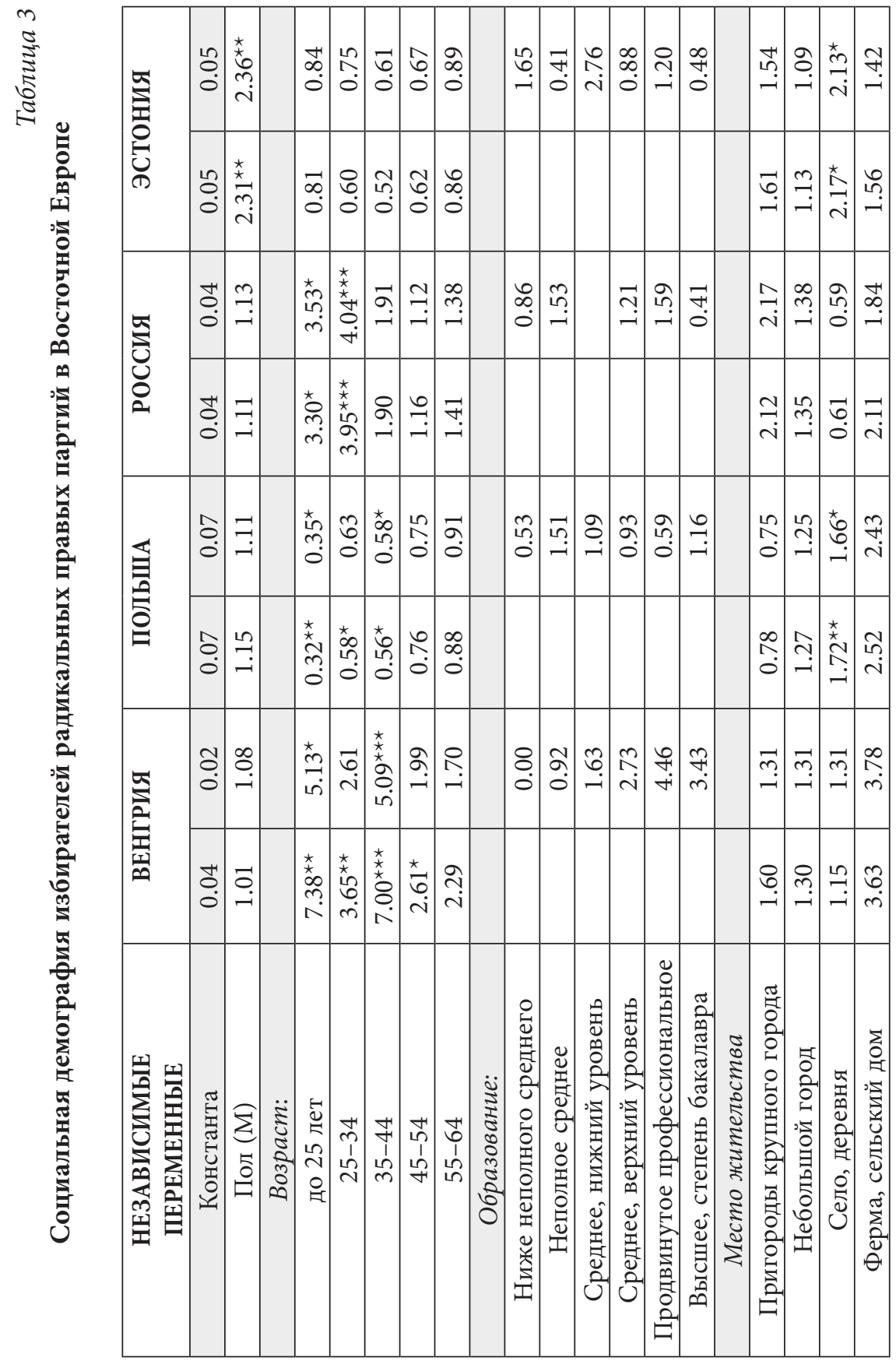


$m$
5
5
0
5
5
0
5
$\vdots$
0
2
$\vdots$
0
0
0

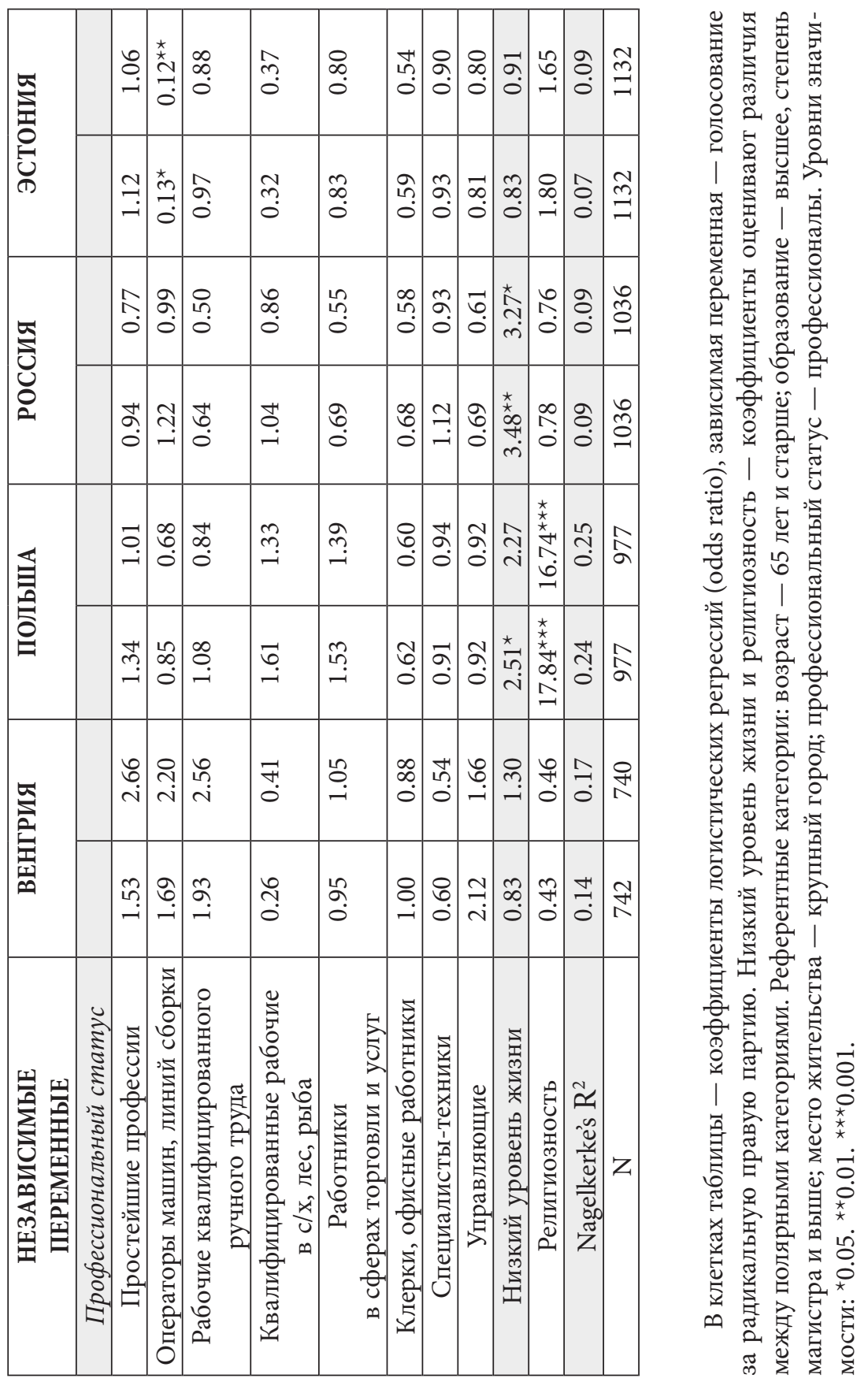


Незначимыми оказались отличия по полу, уровню жизни, религиозности. С уверенностью можно говорить только о возрастных особенностях голосования - за «Йоббик» бросают бюллетени скорее люди среднего возраста - 35-44 года и самые молодые - до 25 лет, менее определенно - 25-34 лет.

Структурирование голосов, отданных в Польше за партию «Право и справедливость» (PiS), имело ряд существенных отличий от других изучавшихся нами стран. Следует иметь в виду, что эта партия, придерживаясь идеологических ориентиров, характерных для радикальных правых, все же в полной мере к этому партийному семейству не относится. Кроме того, она получила большую часть мандатов в Сейм и имела возможность проводить политику, которую поддерживали многочисленные консервативно и националистически настроенные избиратели. Тем не менее PiS была включена в наш анализ, поскольку в опросных данных не содержалось других сведений об интересующих нас организациях. «Право и справедливость» привлекает избирателей из разных социальных слоев, вычленяемых по профессиональному статусу и образованию, - влияние в регрессиях этих переменных было несущественным и за рамками статистической значимости. Среди них в равной мере представлены мужчины и женщины. Их с чуть большей вероятностью можно встретить в сельской местности, чем в городах, и среди людей с низкими доходами. Однако ключевые особенности электората определяли две переменные - религиозность и возраст. Известно, что во многих странах религиозные люди склонны поддерживать консерваторов, но не радикального толка. Такая же закономерность наблюдается в Польше: голосование за $\mathrm{PiS}$ разительно отличается у религиозных и нерелигиозных граждан - первые образуют ее ядерный электорат. Консервативные партии привлекают и более традиционно настроенные старшие поколения, что подтверждается и нашими результатами, в отличие от других изучавшихся партий, получающих большую поддержку в младших и средних возрастных когортах, «Право и справедливость» собирает, напротив, голоса людей старшего возраста.

ЛДПР, представляющая правых националистов и популистов в России (с добавлением малочисленных сторонников Родины), находит своих избирателей в самых разных социально-экономических стратах, вследствие чего ни переменная профессионального статуса, ни образование, как видно в таблице 3, не объясняют того, кто голосует за партию 
В.Ф. Жириновского. Правда, вероятность найти избирателей этой партии повышается по мере снижения уровня жизни - среди тех респондентов, которые сообщали, что им трудно жить на свои доходы. Пол, место жительства и религиозность заметного влияния на голоса не оказывали. Однако они были связаны с возрастом: партия получала большую поддержку со стороны молодых респондентов, относящихся к категориям до 25 лет и 25-34 года.

Социальная демография слабо влияет и на голосование за Консервативную народную партию Эстонии (EKRE). Так, не было найдено отчетливых отличий по образованию, хотя чуть выше была вероятность поддержки в категории «среднее образование, нижний уровень» (но статистически незначимо), а также по профессиональному статусу, за одним исключением - квалифицированные промышленные рабочие были, в отличие от Западной Европы, не склонны отдавать голоса этой партии. Пол, возраст, материальные трудности жизни, религиозность тоже не объясняли интересующее нас электоральное поведение. Отметим, что EKRE была привлекательнее для сельского населения, чем для жителей больших городов, кроме того, среди ее избирателей проще встретить мужчин, чем женщин.

В целом, как следует из приведенных описаний, социально-структурные дифференциации, свидетельствующие о профессиональном положении и образовании индивидов, которые играют ведущую роль при объяснении голосования за радикальные правые партии на Западе, не позволяют в странах Восточной Европы идентифицировать избирателей этого партийного семейства - они могут получить поддержку в разных социальных слоях. В то же время в Польше и России этих избирателей скорее можно найти среди тех, кто испытывает материальные трудности из-за низких доходов. В Эстонии и Польше обнаруживаются также различия, связанные с местом жительства: избирателей правых радикалов можно чаще встретить, как и в некоторых западных странах, среди сельских жителей. Половые отличия в большинстве стран не проявляются, только в Эстонии было зафиксировано преобладание среди электората мужчин. Возрастные особенности, указывающие на избирателей младшего-среднего возраста, как это характерно для Западной Европы, проявлялись в Венгрии и России. В Польше за полурадикальных консерваторов голосовали скорее люди старших возрастов. 


\section{ОСОБЕННОСТИ ВЗГЛЯДОВ И УБЕЖДЕНИЙ ИЗБИРАТЕЛЕЙ РАДИКАЛЬНЫХ ПРАВЫХ ПАРТИЙ}

Исследование воззрений, отличающих сторонников крайних националистических и популистских партий, начнем с рассмотрения результатов корреляционного анализа. Парные корреляции между признаком голосования за эти партии и переменными политических аттитюдов, националистических и консервативных воззрений и ценностных предпочтений приводятся в таблице 4. Кроме переменных, описанных выше в методическом разделе, нами были сконструированы еще два обобщающих индекса, характеризующих политическое недовольство и отношение к иммигрантам и беженцам. Индекс политического недовольства обобщает политические аттитюды, свидетельствующие о неудовлетворенности индивида руководством страны, недоверии политикам, партиям, парламенту, невосприимчивости политической системы к интересам граждан и неудовлетворенности демократией (все эти показатели в каждой стране очень тесно связаны между собой и с латентной переменной, получаемой при факторном анализе методом главных компонент). После изменения полярности шкал и приведения их к общей размерности (от 0 до 1) этот индекс рассчитывался для каждого респондента из стран Восточной Европы как среднее арифметическое указанных четырех шкальных оценок. В западных странах в общее факторное решение входит еще одна переменная, измеряющая степень доверия Европейскому парламенту, поэтому индекс среднего арифметического значения политических аттитюдов подсчитывался с учетом этих оценок. Индекс неприятия иммиграции и бежениев представляет собой среднее арифметическое двух показателей, оказавшихся тесно взаимосвязанными в странах как Западной Европы, так и, правда, менее отчетливо, Восточной Европы: представлений об общественных последствиях иммиграции (для экономики, культуры, повседневной жизни) и аттитюдов к беженцам.

В Австрии, как видно в таблице 4, первый раздел, все переменные политических аттитюдов достаточно тесно коррелируют с голосованием за FPÖ, а также BZÖ: чем больше человек недоволен политикой, тем больше вероятность того, что он отметит в бюллетене эту партию. Коэффициент корреляции для общего индекса политического недовольства равняется 0.37 ( $\mathrm{p}<0.000)$. В Нидерландах такие зависимости с предпочтением «Партии свободы» наблюдаются с не меньшей определенностью. Коэффициент корреляции для общего индекса имеет значение $0.34(\mathrm{p}<0.000)$. 


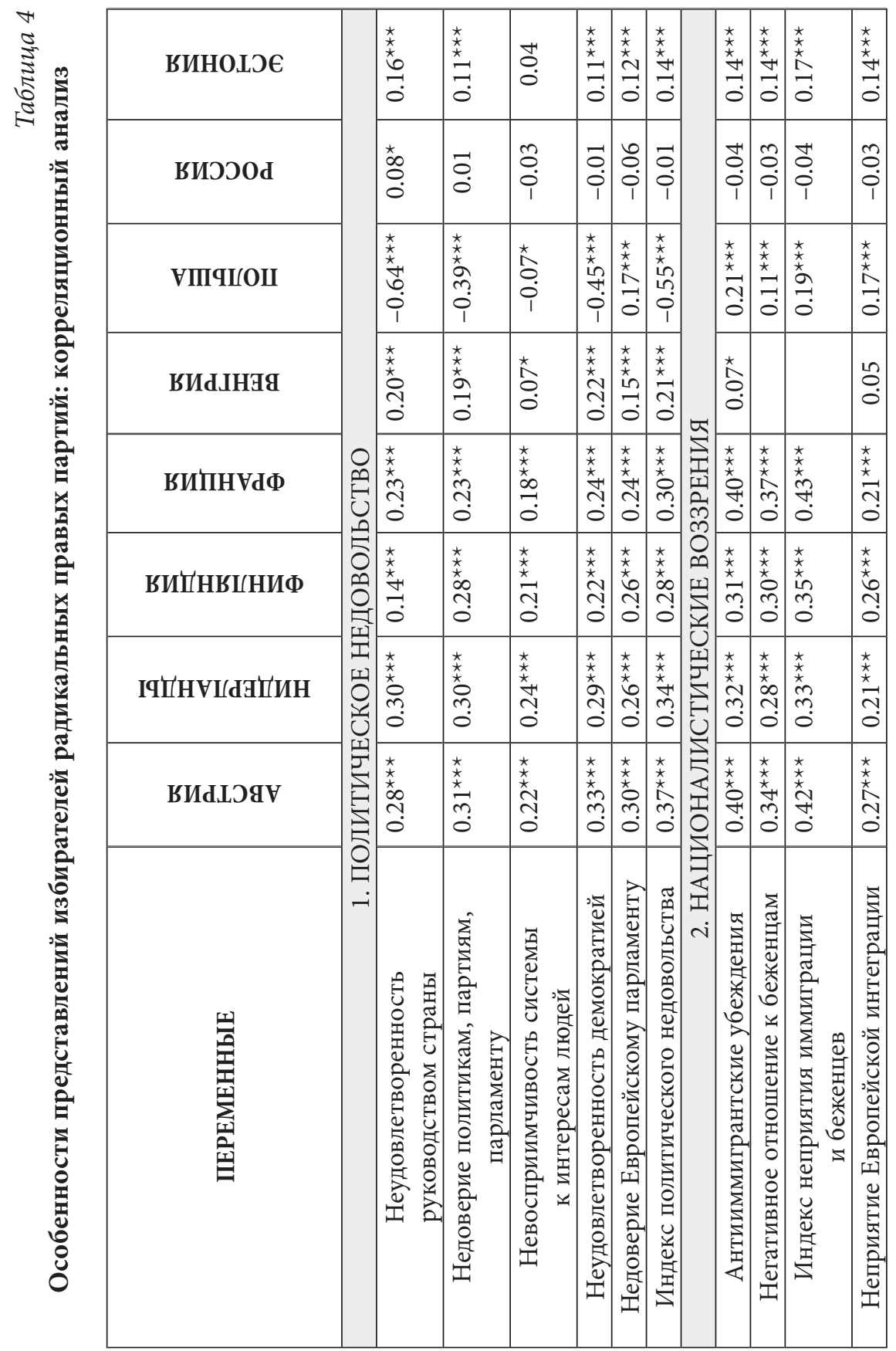




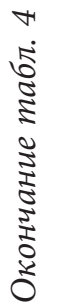

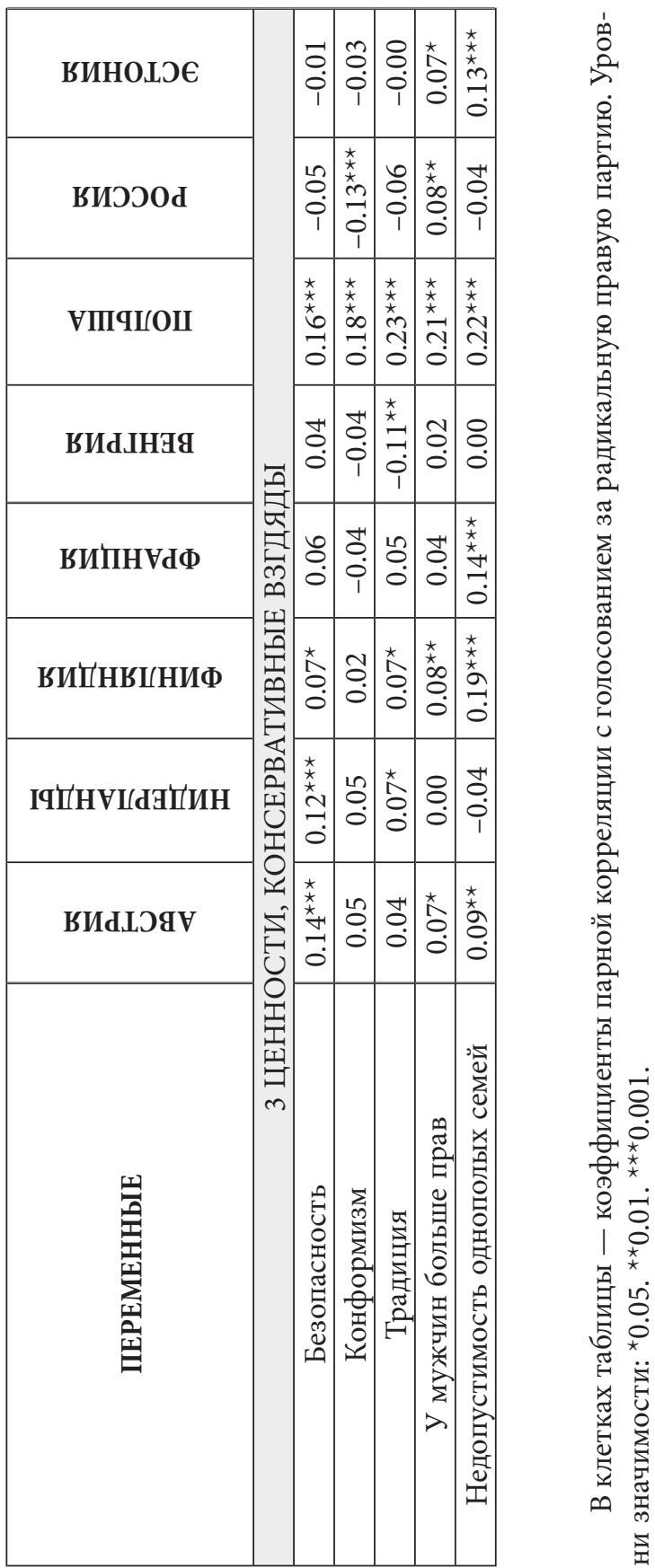


Немного менее отчетливо подобные связи проявляются в Финляндии: избиратели партии «Истинные финны», как правило, недовольны политикой - значение корреляции для индекса равно $0.28(\mathrm{p}<0.000)$. Аналогичным образом дела обстоят во Франции, где этот индекс связан с голосованием за Национальный фронт на уровне $0.30(\mathrm{p}<0.000)$.

Сведения о корреляциях в странах Восточной Европы также можно найти в таблице 4. В Венгрии за «Йоббик» отдают свои голоса люди, неудовлетворенные руководством, политиками, партиями, парламентом и тем, как работает в стане демократическая система, но такие зависимости выражены с заметно меньшей отчетливостью, чем в странах Запада. Корреляция с индексом политического недовольства -0.21 $(\mathrm{p}<0.000)$. «Право и справедливость» в Польше, получившая большинство парламентских мест и играющая ведущую роль в выработке политики страны, получает свои голоса от тех, кто во время опроса с удовлетворением отмечал произошедшие политические перемены. Bсе коэффициенты связей голосования за PiS с аттитюдами к национальным политическим структурам (шкалы выраженности недовольства) оказались отрицательными и очень большими (исключая переменную восприимчивости системы к интересам людей). Коэффициент корреляции для обобщающего эти аттитюды индекса имеет значение -0.55 ( $<<0.000)$. Это значит, что сторонники партии Я. Качиньского через полгода после выборов с удовлетворением высказывались о новом руководстве страны, политических институтах и работе польской демократии. При этом они были склонны с подозрением относиться к Европейскому парламенту $(\mathrm{r}=0.17, \mathrm{p}<0.000)$. В России на выбор ЛДПР (или «Родины») при избрании Государственной Думы никакие политические аттитюды влияния не оказывали. Все корреляции были ничтожно малыми, статистически незначимыми. Только с показателем неудовлетворенности руководством страны получена слабая, но значимая связь $(\mathrm{r}=0.08$, $\mathrm{p}<0.014)$, говорящая о чуть большей вероятности голосования среди тех, кто был недоволен властями. Наконец, для избирателей «Консервативной народной партии Эстонии» характерным является недовольство властями и политическими институтами страны и недоверие Европейскому парламенту, однако все эти корреляции были достаточно слабыми, хотя и статистически значимыми на высоком уровне. Так, коэффициент корреляции, связывающий голосование за эту партию с общим индексом политических аттитюдов, равняется всего лишь 0.14 $(\mathrm{p}<0.000)$. 
Приверженность антииммигрантским убеждениям и негативное отношение к беженцам, как показано во втором разделе таблицы 4, оказывают во многих странах очень сильное влияние на электоральную поддержку радикальных правых партий. Как отдельные показатели, так и общий индекс, измеряющие эту приверженность, тесно сопряжены с таким поведением на выборах. В Австрии коэффициент корреляции для индекса неприятия иммиграции и беженцев достигает 0.42, во Франции -0.43 , в Нидерландах и Финляндии он был немного меньше -0.33 и 0.35 соответственно (для всех значений $\mathrm{p}<0.000$ ). Кроме того, те, кто голосует в западных странах за правых радикалов, склонны считать, что объединение Европы зашло уже слишком далеко. Коэффициент, указывающий на такую связь, был в Австрии равен 0.27 , в Финляндии 0.26 , а в Нидерландах и Франции -0.21 ( $<<0.000$ для всех значений).

Аналогичных взглядов придерживаются и голосующие за соответствующие партии в Польше и Эстонии, хотя зависимости в них проявлялись с гораздо меньшей определенностью. Так, корреляции с индексом отношения к иммиграции и беженцам составляли в той и другой стране 0.19 и 0.17 , а с показателем неприятия европейской интеграции -0.17 и 0.14 (все при $\mathrm{p}<0.000$ ). В Венгрии отрицательное отношение к иммиграции (об отношении к беженцам массив сведений не содержит) коррелировало с голосованием совсем слабо, а коэффициент для шкалы объединения Европы и вовсе оказался за пределами значимости. В России националистические воззрения, измеренные любым из обсуждавшихся показателей, на электоральную поддержку ЛДПР не влияли.

В Западной Европе ценности, свидетельствующие о важности для индивида безопасности, послушания и следования традициям, которые могут резонировать с авторитарно-консервативными идеологическими установками радикальных партий правого толка, едва ли в действительности мотивируют исследуемое электоральное поведение. Все связи оказались очень слабыми, и только о некоторых из них можно было сказать, что они являются неслучайными. Наиболее заметные корреляции оказались с ценностью безопасности: 0.14 в Австрии, 0.12 в Нидерландах (ниже в Финляндии и Франции -0.07 и 0.06 ). Незначительную роль играют и консервативные представления о преимуществе мужчин при приеме на работу (в Австрии и Франции статистически значимые, но более чем скромные корреляции были 0.07 и 0.08). Важнее были убеждения о недопустимости воспитания детей 
в семьях с однополыми родителями: в Финляндии корреляция составляла 0.19, во Франции 0.14, в Австрии 0.09 (при высоких уровнях значимости), правда, в Нидерландах, известной социально-культурными либеральными предпочтениями, такой зависимости не обнаружено.

Значение ценностных предпочтения и консервативных ориентаций в странах Восточной Европы было достаточно скромным. Польша, надо признать, составляет исключение - голосующие за $\mathrm{PiS}$ проявляли определенную склонность к ценностям безопасности ( $\mathrm{r}=0.16)$, подчинения (0.18), соблюдения традиций (0.23), а также полагали, что мужчины должны иметь преимущества перед женщинами при приеме на работу $(\mathrm{r}=0.21)$, и выступали против разрешения однополым брачным парам растить детей (0.22) (р<0.000 для всех коэффициентов). В Эстонии тоже проявлялось несильное воздействие переменной, свидетельствующей о неприятии однополых семей $(0.13, \mathrm{p}<0.000)$, а в России и Эстонии - очень слабое влияние ориентаций на гендерное неравенство в трудовой сфере (соответственно 0.08, р<0.009, и 0.07, р<0.017). Остальные коэффициенты были статистически незначимыми или, при значимости, имели противоположный знак, что противоречило предположениям о ценностных мотивациях голосования.

В целом анализ парных корреляций между аттитюдами и голосованием за радикальные правые партии свидетельствует, что в странах Западной Европы ключевым фактором их поддержки выступает негативное отношение избирателей к иммигрантам и беженцам, а также (в меньшей степени) неприятие дальнейшего объединения Европы. С полной определенностью проявляется влияние политического недовольства, как национальными властями и институтами, так и Европейским парламентом. Ценности и убеждения, созвучные авторитарным и консервативным аспектам идеологии этих партий, существенного значения, за отдельными исключениями, не имеют. В таких странах Восточной Европе, как Венгрия и Эстония, политическое недовольство также играет мотивирующую роль, хотя соответствующие зависимости выражены слабее, чем на Западе. В Эстонии, кроме того, заметным было и воздействие националистических взглядов - неприятия иммигрантов, беженцев и Европейской интеграции. Еще чуть большим значение таких националистических ориентаций было в Польше. И только в этой стране предпочтения безопасности, подчинения, традиций и консервативные взгляды вполне определенно были связаны с поддержкой PiS. Политика с приходом к власти этой партии вызывала у ее электората 
понятное одобрение. В России никакие взгляды и предпочтения не коррелировали сколько-нибудь заметно с предпочтением на выборах ЛДПР.

\section{ГОЛОСОВАНИЕ ЗА РАДИКАЛЬНЫЕ ПРАВЫЕ ПАРТИИ: ОСНОВНЫЕ ДЕТЕРМИНАНТЫ}

Поиск наиболее существенных факторов, оказывающих самостоятельное воздействие на электоральную поддержку радикальных правых партий, вновь осуществлялся с помощью логистических регрессий. В число независимых переменных включались показатели, которые, согласно нашему предшествующему анализу, были в большинстве стран отчетливо связаны с такой поддержкой (и не вызывали резкого сокращения численности респондентов из-за отсутствия ответов). Среди них демографические признаки (возраст при контроле пола), важнейшая социально-структурная характеристика - образование, политические аттитюды (индекс политического недовольства, а в Восточной Европе дополнительно - переменная отношения $к$ Европейскому парламенту) и националистические взгляды (индекс неприятия иммиграции и беженцев и шкала неприятия Европейской интеграции). Каждая страна описывается тремя регрессиями: первая позволяет прояснить значение политического недовольства при учете социальной демографии, вторая - националистических представлений при социально-демографическом контроле, а третья - обоих факторов при их одновременном включении в регрессионное уравнение (odds ratios для этих переменных говорят об их влиянии на голосование при изменении на одно стандартное отклонение).

Результаты для Западной Европы можно найти в таблице 5. Политическое недовольство во всех четырех странах порождает сильную мотивацию голосования за интересующие нас партии. Об этом свидетельствуют статистически значимые на высоком уровне регрессионные коэффициенты (odds ratio в первых моделях), по значению превышающие единицу: в Австрии - 3.13, Нидерландах - 2.58, Финляндии - 2.10 и Франции - 2.54. Еще сильнее побуждала к голосованию приверженность националистическим убеждениям, особенно негативное отношение респондентов к иммиграции и беженцам. Коэффициенты для перечисленных стран соответственно равняются 3.66, 2.60, 2.21 и 4.52 (все при $\mathrm{p}<0.000)$. Но и переменная критического отношения к дальнейшему объединению Европы оказывала статистически значимое воздействие, хотя и менее выраженное (становится незначимым в третьих 
моделях вследствие нередкого сочетания таких представлений с политической неудовлетворенностью).

Политические аттитюды и националистические ориентации существенно улучшают в Западной Европе объяснительные возможности регрессий по сравнению с моделями, содержащими только социальную демографию (последние не приводятся). Так, добавление индекса недовольства политикой повышает в Австрии Nagelkerke’s R ${ }^{2}$ с 9 до 30 \%, включение обеих переменных национализма - до 36 \%, а когда учитывались и политические и националистические взгляды, значение этого показателя достигало 41 \%. В Нидерландах политическое недовольство приводит к изменению $\mathrm{R}^{2}$ от 11 к 26 \%, национализм увеличивает его до $28 \%$, а оба фактора - до 35 \%. Соответствующие изменения регрессий в Финляндии - с 13 до 23 \% в модели с политическими аттитюдами, в уравнении с признаками национализма - до 29 \% и, наконец, с теми и другими - до 32 \%. Во Франции - с 13 до 25 \% (политика), далее - до 41 \% (национализм), и в модели со всеми переменными значение оставалось равным $41 \%$.

Приведенные коэффициенты и проценты улучшения моделей подтверждают, что политическое недовольство и национализм играют существенную роль в электоральной поддержке радикальных правых партий в Западной Европе. Важнейшей причиной такой поддержки является нативизм, националистическая ориентация их идеологии, находящая понимание у избирателей, опасающихся растущих потоков иммигрантов и беженцев. Но и неудовлетворенность политикой остается очень существенным самостоятельным фактором голосования за правых радикалов, хотя она достаточно тесно связана с националистическими взглядами - разочарование политикой в немалой мере вызывается обострением проблемы иммигрантов и беженцев (в объединенном массиве данных четырех западных стран корреляция этих переменных, Pearson's $r,=0.46, \mathrm{p}<0.000)$. Политическая неудовлетворенность резонирует с популистской риторикой радикальных партий, в которой клеймятся действующие власти и политические институты как обслуживающие исключительно интересы коррумпированных элит, но не простого народа. 


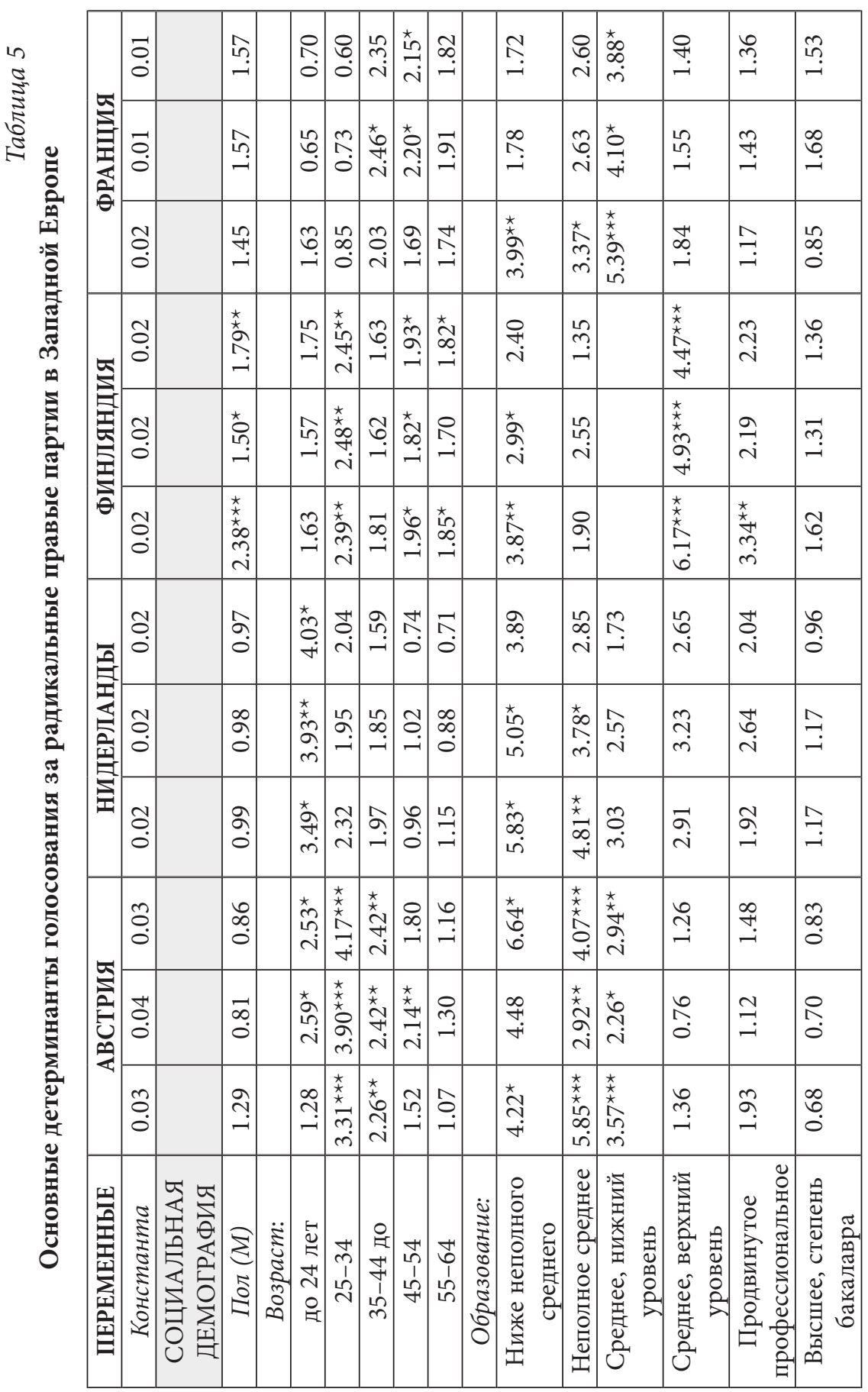


$n$
5
5
0
5
5
0
5
5
5
5
5
0
0
0

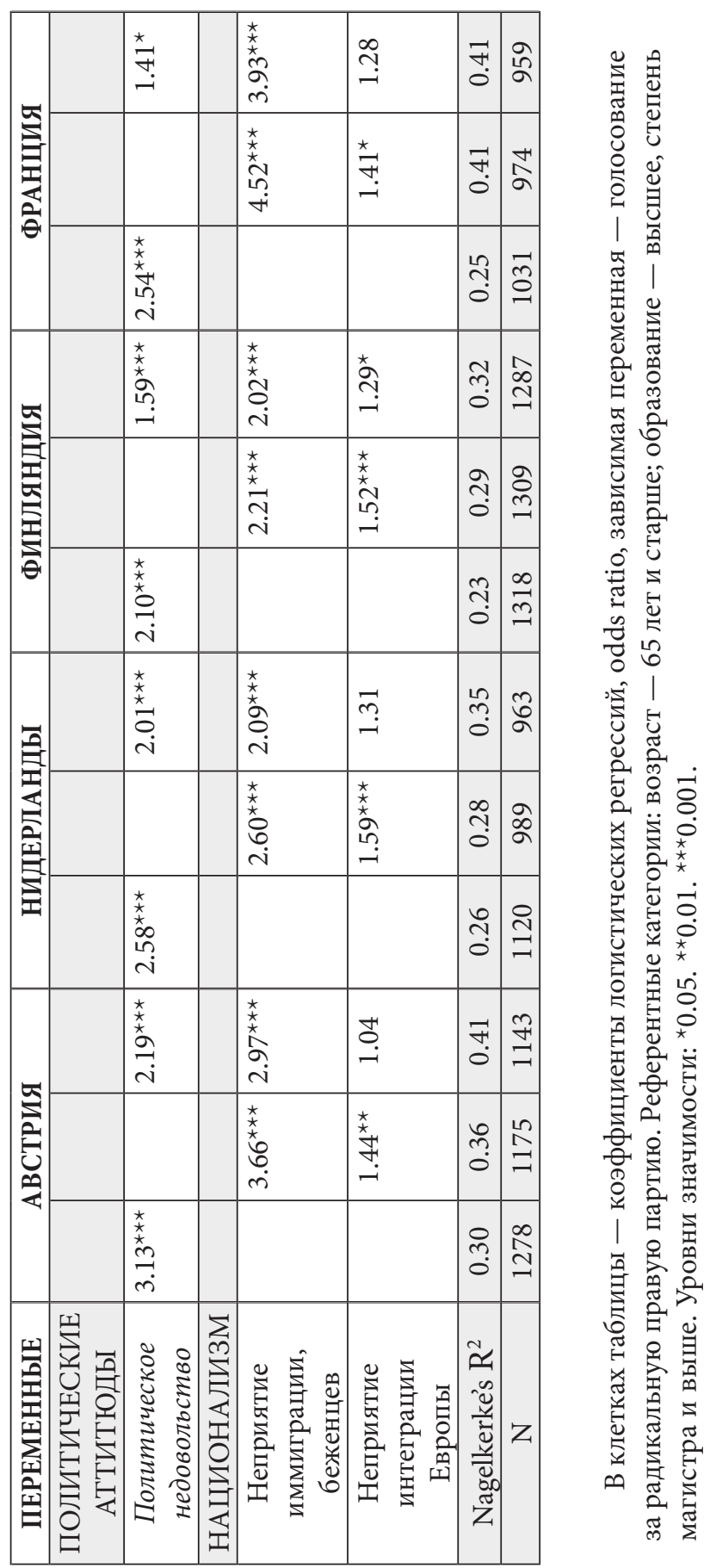


Регрессионные результаты для Восточной Европы, полученные в таких же моделях, как для стран Запада, сведены в таблицу 6 (многие респонденты не имели мнения по вопросам, использовавшимся для конструирования показателей взглядов и убеждений, поэтому «missing data» превышает треть участников опросов).

Согласно табличным данным для Венгрии, недовольство национальными властями и политическими структурами подталкивает избирателей к предпочтению партии «Йоббик» перед ее конкурентами. Объяснительный потенциал модели (Nagelkerke’s $\mathrm{R}^{2}$ ) при этом заметно возрастает по сравнению с уравнением с одной социальной демографией - с 12 до 24 \%. Националистические взгляды существенного значения не имели.

В Польше электорат PiS c некоторым подозрением относился к Европейскому парламенту. Определенное значение имело и негативное отношение к иммигрантам и беженцам (небольшие, но неслучайные коэффициенты, улучшение модели с 11 до 14 \%). Но главным в этой стране, как уже отмечалось, было позитивное отношение избирателей этой партии к политическим переменам, вызванным приходом склонных к радикализму консерваторов во власть. Поэтому как раз удовлетворенность руководителями страны, политическими институтами и демократией оказывала в регрессиях очень сильное воздействие на голосование (статистически значимые odds ratio, по величине много меньшие единицы). Значение $\mathrm{R}^{2}$ с учетом этого фактора достигает $51 \%$.

Если говорить о России, то кроме ранее описанных отчетливых возрастных различий, свидетельствующих о диспропорциональном представительстве голосующих за ЛДПР в младших возрастных категориях, ни политическая неудовлетворенность, ни националистические ориентации, как и следовало ожидать после корреляционного анализа, никак не проясняли вопроса о взглядах и позициях этого электората.

В Эстонии политическая неудовлетворенность слабо влияла (хотя статистически значимо) на голоса за EKRE. Немного сильнее было воздействие националистических представлений - значение $\mathrm{R}^{2}$, равное $12 \%$ в уравнении с одной социальной демографией, увеличивается почти до 15 \%. Политические и националистические ориентации, при совместном включении в уравнение регрессии, оказываются значимыми самостоятельными факторами, увеличивая этот показатель до 18 \%.

Таким образом, описанные зависимости для стран Восточной Европы, вопреки встречающимся в литературе утверждениям о чуть 
ли не прямо противоположных ориентациях, которые мотивируют в этих странах и на Западе голосование за радикальные правые партии, свидетельствуют, что на него скорее сходным образом воздействуют одни и те же социальные представления. Только их влияние в первых проявлялось с гораздо меньшей отчетливостью, чем во вторых. Исключение составляет Россия, в которой, кроме возрастных особенностей, других зависимостей обнаружено не было.

\section{ЗАКЛЮЧИТЕЛЬНЫЕ ЗАМЕЧАНИЯ}

Проведенное исследование позволило подтвердить и уточнить сложившиеся научные представления об особенностях электората радикальных правых партий в странах Западной Европы, показав, что они диспропорционально сосредоточены в нижних общественных слоях - среди людей с невысоким уровнем образования и социально-профессионального статуса, а также в рядах избирателей младшего и среднего возраста. Признанные различия по полу, говорящие о более вероятной поддержке со стороны мужчин, чем женщин, не относятся к числу общих для изучавшихся стран закономерностей (обнаружены только в одной из четырех). Но главные отличия этого электората связаны с высоким недоверием властям и политическим институтам и неприязненным отношением к иммигрантам и беженцам. Можно утверждать, что голосование в полной мере отвечает на идеологическое предложение националистических популистских партий.

В Восточной Европе также проявлялись демографические различия, указывающие на более вероятную принадлежность избирателей радикальных партий с националистическим уклоном к младшим или средним возрастам (преобладание мужчин отмечалось только в одной из стран), но консерваторов в Польше поддерживали пожилые. Социально-экономическое структурирование, связанное с образованием и профессиональным статусом, существенной роли в голосовании не играло. Для этих избирателей характерны недовольство политикой (в Польше - удовлетворенность ею, поскольку $\mathrm{PiS}$ доминировала во власти) и националистические взгляды, однако эти зависимости были не такими сильными, как в западных странах. В Польше с полной определенностью действовали факторы, связанные с консервативным настроем электората - религиозностью и ценностными ориентациями на безопасность, послушание, соблюдении традиций (что связано, 


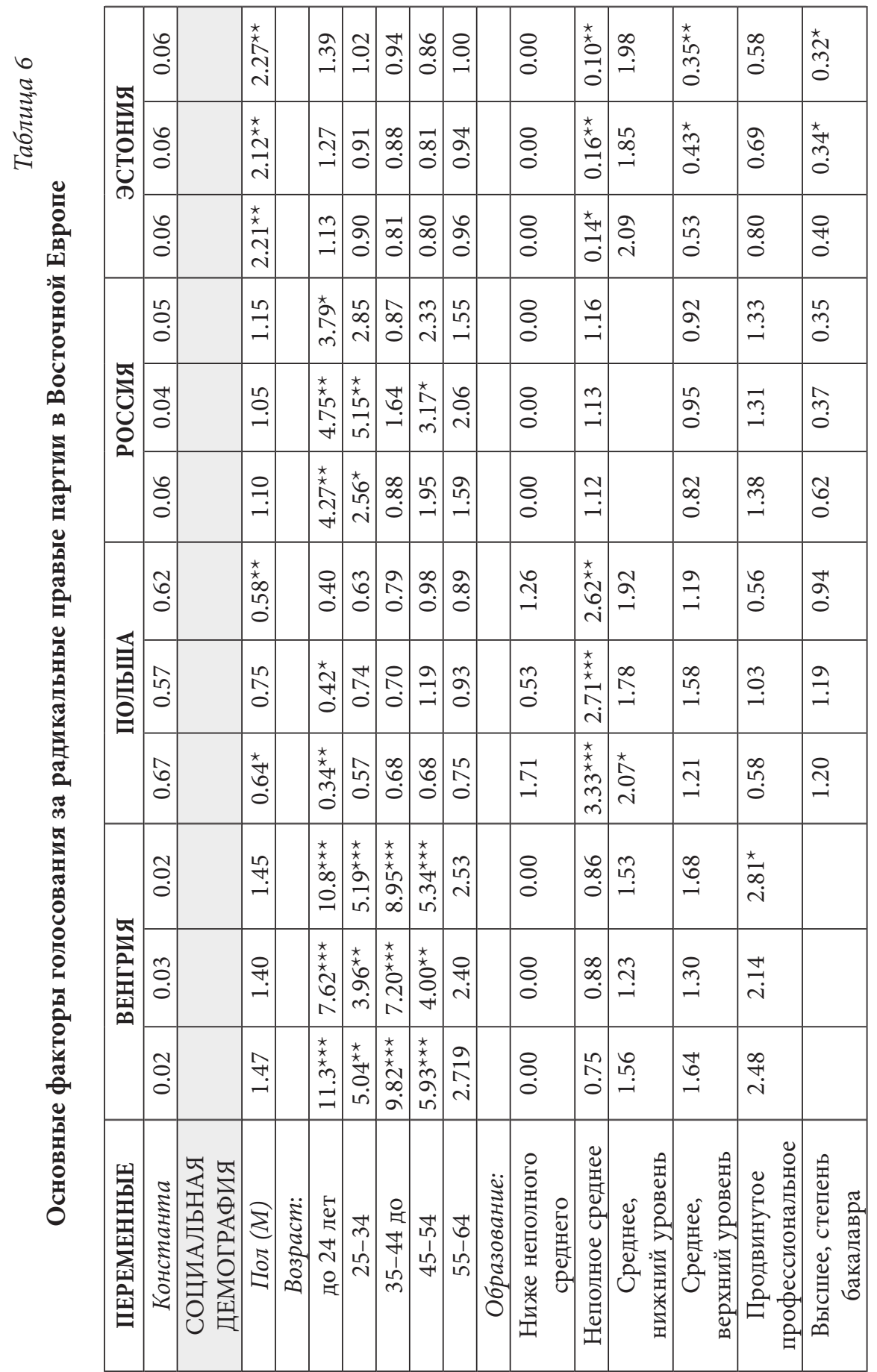




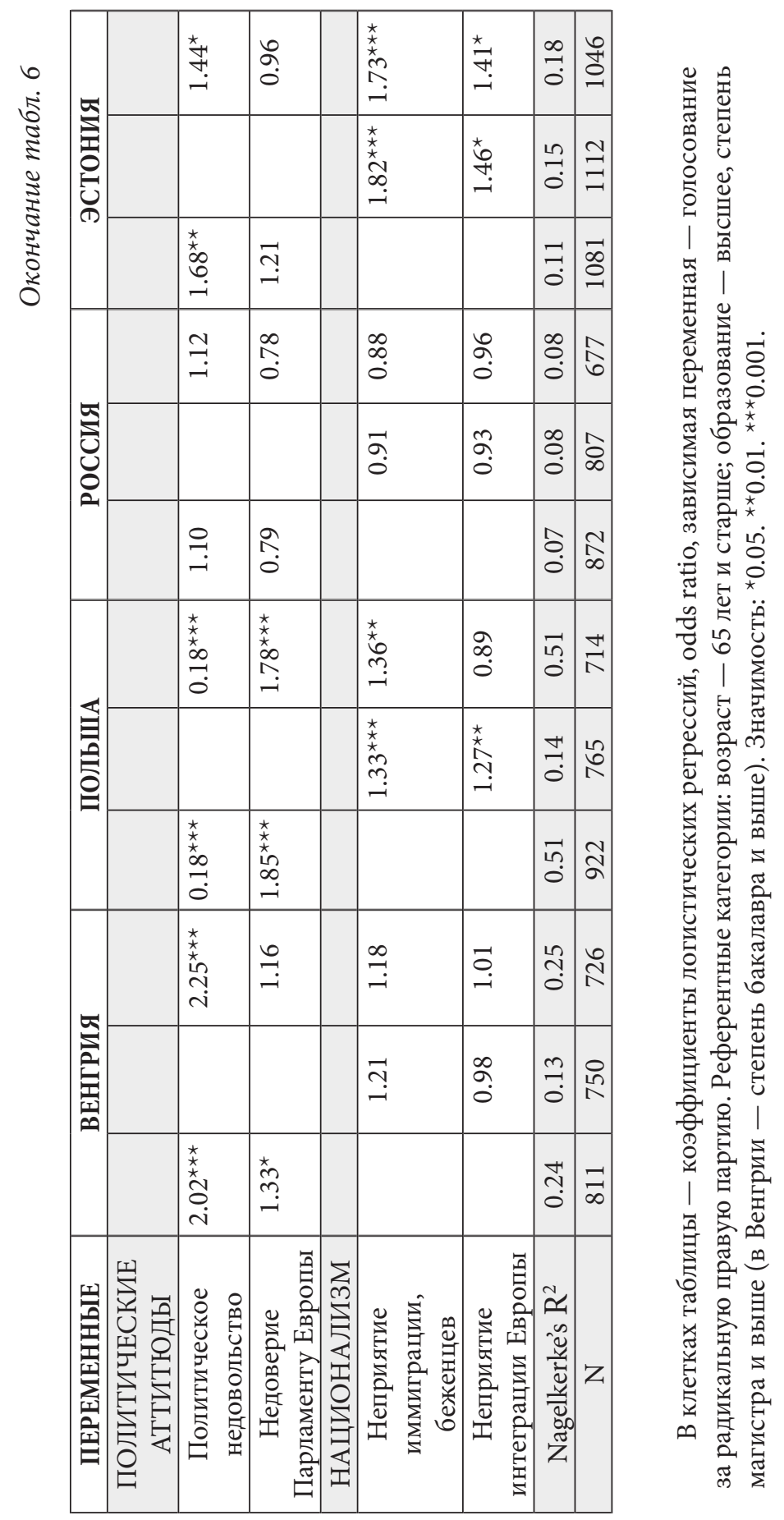


по-видимому, с идеологическим позиционированием PiS между консерваторами и правыми радикалами).

Несмотря на использование широкого набора разнообразных переменных индивидуальных различий (не только рассмотренных в настоящей работе, но и практически всех хоть сколько-нибудь релевантных поставленным задачам переменных, содержащихся в данных ESS 2016), нам так и не удалось обнаружить в России ясных отличительных признаков сторонников националистической популистской риторики ЛДПР. В научной литературе, посвященной выборам в Государственную Думу, можно найти указания на такие признаки. Так, в 2016 г. анализ голосования за четыре парламентские партии с использованием опросных данных, собранных после выборов ГД, продемонстрировал, что в электорате ЛДПР можно с большей вероятностью обнаружить мужчин, чем женщины, избирателей с невысоким уровнем жизни, недовольных состоянием российской экономики, не выражающих безусловного одобрения президенту В.В. Путину, не считающих, что ситуация с коррупцией улучшилась по сравнению с советскими временами, а также тех, кто знакомится с новостями в интернете - вследствие заметного использования этой партией Сети в предвыборной кампании [Hutcheson, McAllister 2017: table 9]. Однако все эти особенности отличают голосующих за ЛДПР от тех, кто поддержал «Единую Россию». При попытке найти ее отличительные признаки от всех остальных парламентских партий, как это предполагалось в нашем сравнительном исследовании, такие зависимости могут стираться, поскольку избиратели КПРФ и «Справедливой России» разнятся со сторонниками партии власти по тем же самым признакам, что и выбравшие Либеральных демократов, кроме использования Сети. Наш дополнительный анализ также показывает, что избиратели ЛДПР, кроме чуть большего представительства в младших возрастах, действительно чаще пользуются интернетом, хотя такая связь была довольно слабой $(\mathrm{r}=0.13, \mathrm{p}<0.000)$. Отвечая на ценностный вопросник, они нередко признаются (корреляции тоже слабые), что для них в жизни важны достижения ( $\mathrm{r}=0.13, \mathrm{p}<0.000)$. Среди ценностных ориентаций указана и «возможность повеселиться, заняться тем, что доставляет удовольствие» $(\mathrm{r}=0.13, \mathrm{p}<0.000)$. Так что некоторых сторонников ЛДПР привлекает, вероятно, не столько ее идейный уклон в национализм и популизм, сколько экстравагантное поведение лидера, удовлетворяющее эту потребность. 


\section{Литература}

Сафронов В.В. Голосование за радикальные правые партии в Европе: роль культурного изменения и партийной поляризации (часть 1) // Телескоп: журнал социологических и маркетинговых исследований. 2018. № 6. С. 15-22.

Сабронов В.В. Голосование за радикальные правые партии в Европе: роль культурного изменения и партийной поляризации (часть 2) // Телескоп: журнал социологических и маркетинговых исследований. 2019. № 1. С. 2-11.

Arzheimer K. Contextual Factors and the Extreme Right Vote in Western Europe, 1980-2002 // American Journal of Political Science. 2009. Vol. 53, № 2. P. 259-275.

Arzheimer K. Electoral Sociology: Who Votes for the Extreme Right and Why and When? // The Extreme Right in Europe: Current Trends and Perspectives / ed. by U. Backes, P. Moreau. Göttingen: Vandenhoeck and Ruprecht, 2011. P. 35-50.

Arzheimer K., Carter E. Political Opportunity Structures and Right-Wing Extremist Party Success // European Journal of Political Research. 2006. Vol. 45, № 3. P. 419-443.

Arzheimer K. Explaining Electoral Support for the Radical Right // The Oxford Handbook of the Radical Right / ed. by J. Rydgren. N.Y.: Oxford University Press, 2018. P. 143-165.

Bornschier S. Globalization, Cleavages, and the Radical Right // The Oxford Handbook of the Radical Right / ed. by J. Rydgren. N.Y.: Oxford University Press, 2018. P. 212-238.

Bustikova L. Revenge of the Radical Right // Comparative Political Studies. 2014. Vol. 47, № 12. P. 1738-1765.

Buštiková L. The Radical Right in Eastern Europe // The Oxford Handbook of the Radical Right / ed. by J. Rydgren. N.Y.: Oxford University Press, 2018. P. 565-581.

Coffé H. Gender and the Radical Right // The Oxford Handbook of the Radical Right / ed. by J. Rydgren. N.Y.: Oxford University Press, 2018. P. 200-211.

ESS Round 8: European Social Survey Round 8 Data. Data file edition 2.1. NSD - Norwegian Centre for Research Data. Norway - Data Archive and distributor of ESS data for ESS ERIC. 2016.

ESS8. Appendix A1: Education. 2016. URL: http://www.europeansocialsurvey. org/docs/ round8/survey/ESS8_appendix_a1_e02_2.pdf (дата обращения: 16.03.2020).

Golder M. Far Right Parties in Europe // Annual Review of Political Science. 2016. Vol. 19. P. 477-497.

Hutcheson D.S., McAllister I. Explaining Party Support in the 2016 State Duma Election // Russian Politics. 2017. Vol. 2, № 4. P. 454-481.

Ignazi P. The Silent Counter-Revolution. Hypotheses on the Emergence of Extreme Right-Wing Parties in Europe // European Journal of Political Research. 1992. Vol. 22, № 1. P. 3-34.

Inglehart R., Norris P. Trump, Brexit, and the Rise of Populism: Economic HaveNots and Cultural Backlash // HKS Working Paper. No. RWP16-026. 2016. 
International Labour Office. International Standard Classification of Occupations: ISCO 08. Vol. I. Geneva: ILO. 2012. URL: <http://www.ilo.org/public/english/bureau/ stat/isco/isco08/ (дата обращения: 16.03.2020).

Ivarsflaten E. What unites right-wing populists in Western Europe? // Comparative Political Studies. 2008. Vol. 41, № 1. P. 3-23.

Kehrberg J.E. The demand side of support for radical right parties // Comparative European Politics. 2015. Vol. 13, № 5. P. 553-576.

Kitschelt H. Growth and Persistence of the Radical Right in Postindustrial Democracies: Advances and Challenges in Comparative Research // West European Politics. 2007. Vol. 30, № 5. P. 1176-1206.

Kitschelt H. Party Systems and Radical Right-Wing Parties // The Oxford Handbook of the Radical Right / ed. by J. Rydgren. N.Y.: Oxford University Press, 2018. P. 166-199.

Kriesi H., Grande E., Dolezal M., Helbling M., Hëoglinger D., Hutter S., Wëuest B. Political Conflict in Western Europe. N.Y.: Cambridge University Press, 2012. $368 \mathrm{p}$.

Kriesi H., Grande E., Lachat R., Dolezal M., Bornschier S., Frey T. West European Politics in the Age of Globalization. N.Y.: Cambridge University Press, 2008. 448 p. Lubbers M., Coenders $M$. Nationalistic attitudes and voting for the radical right in Europe // European Union Politics. 2017. Vol. 18, № 1. P. 98-118.

Lubbers M., Gijsberts M., Scheepers P. Extreme right-wing voting in Western Europe // European Journal of Political Research. 2002. Vol. 41, № 3. P. 345-378.

Minkenberg M. (ed.). Transforming the Transformation? The East European radical right in the political process. L.; N.Y.: Routledge, 2015. 376 p.

Mudde C. Populist Radical Right Parties in Europe. N.Y.: Cambridge University Press, 2007. 404 p.

Mudde C. The Study of Populist Radical Right Parties: Towards a Fourth Wave // C-REX Working Paper Series. 2016. № 1.

Mudde C. Politics at the Fringes? Eastern Europe's Populist, Racist, and Extremist // The Routledge Handbook of East European Politics / ed. by A. Fagan, P. Kopecký. L.: Routledge, 2017. P. 254-263.

Muis J., Immerzeel T. Causes and Consequences of the Rise of Populist Radical Right Parties and Movements in Europe // Current Sociology Review. 2017. Vol. 65, № 6. P. 909-930.

Norris P. Radical Right: Voters and Parties in the Electoral Market. N.Y.: Cambridge University Press, 2005. 363 p.

Norris P., Inglehart R. Cultural Backlash: Trump. Brexit. and Authoritarian Populism. N.Y.: Cambridge University Press, 2019. 564 p.

Oesch D. Explaining Workers' Support for Right-Wing Populist Parties in Western Europe: Evidence from Austria, Belgium, France, Norway, and Switzerland // International Political Science Review. 2008. Vol. 29, № 3. P. 349-373. 
Oesch D. The Class Basis of the Cleavage between the New Left and the Radical Right: an analysis for Austria, Denmark, Norway and Switzerland // Class Politics and the Radical Right / ed. by J. Rydren. L.: Routledge, 2012. P. 31-51.

Rooduijn M. What unites the voter bases of populist parties? Comparing the electorates of 15 populist parties // European Political Science Review. 2018. Vol. 10, № 3. P. 351-368.

Rydgren J. Immigration Sceptics, Xenophobes, or Racists? Radical Right-wing Voting in Six West European Countries // European Journal of Political Research. 2008. Vol. 47, № 6. P. 737-765.

Rydgren J. The Radical Right: An Introduction // The Oxford Handbook of the Radical Right / ed. by J. Rydgren. N.Y.: Oxford University Press, 2018. P. 1-14.

Santana A., Zagórski P., Rama J. At Odds with Europe: Explaining Populist Radical Right Voting in Central and Eastern Europe // East European Politics. 2020. Vol. 36. № 2. P. 288-309.

Schwartz S.H. Universals in the content and structure of values: Theoretical advances and empirical tests in 20 countries // Advances in experimental social psychology. 1992. Vol. 25. P. 1-65.

Schwartz S.H. A Proposal for Measuring Value Orientations across Nations // European Social Survey Core Questionnaire Development. L.: European Social Survey; City University London. 2001. P. 259-319.

Schwartz S.H. An Overview of the Schwartz Theory of Basic Values // Online Readings in Psychology and Culture. 2012. Vol. 2 (1). URL: http://dx.doi. org/10.9707/2307-0919.1116 (дата обращения: 16.03.2020).

Stockemer D., Lentz T. Mayer D. Individual Predictors of the Radical Right-Wing Vote in Europe: A Meta-Analysis of Articles in Peer-Reviewed Journals [1995-2016] // Government and Opposition. 2018. Vol. 53, № 3. P. 569-593.

Werts H., Scheepers $P$., Lubbers M. Euro-scepticism and radical right-wing voting in Europe, 2002-2008: Social cleavages, socio-political attitudes and contextual characteristics determining voting for the radical right // European Union Politics. 2013. Vol. 14, № 2. P. 183-205. 


\title{
VOTERS OF RADICAL RIGHT PARTIES IN EUROPE: SOCIO-DEMOGRAPHICS, POLITICAL ATTITUDES, NATIONALISM
}

\author{
V.V. Safronov
}

\author{
(vsafronov@list.ru) \\ Sociological Institute of the Russian Academy of Sciences - \\ a branch of the Federal Center of Theoretical and Applied Sociology \\ of the Russian Academy of Sciences, \\ St. Petersburg, Russia»
}

Citation: Safronov V. Izbirateli radikal'nyh pravyh partij v Evrope: social'naya demografiya, politicheskie attityudy, nacionalizm [Voters of radical right parties in Europe: socio-demographics, political attitudes, nationalism]. Vlast' $i$ elity [Power and Elites] , 2020, 7 (2): 22-63. (In Russian)

DOI: https://doi.org/10.31119/pe.2020.7.2.5

\begin{abstract}
The article discusses the distinctive characteristics of voters of radical right-wing parties in Western and Eastern Europe. The patterns identified in numerous Western studies are now being questioned and there are fundamental differences between such voters in one part of the continent and another. Empirical verification of these claims was carried out using data from the European Social Survey 2016-2017 (ESS, Round 8) for four Western countries (Austria, the Netherlands, Finland and France) and four Eastern countries (Estonia, Hungary, Poland and Russia). The results allow confirming and clarifying scientific conclusions about the characteristics of the electorate of radical right-wing parties in Western Europe. In this electorate, citizens with low education and socioprofessional status, younger and middle-age cohorts are disproportionately represented (the representation of men and women was similar, although there were exceptions to this rule). But the main differences of voters are related to high dissatisfaction with the authorities and political institutions, and hostility to immigrants and refugees. In Eastern Europe, voting for radical nationalist parties was also more likely to be found in younger and middle-aged groups (male predominance was also not a common pattern), but neither education nor professional status played a significant role. The voters are also characterized by discontent with politics (in Poland, satisfaction with it because the party studied won the election) and nationalistic views, but these influences were not as strong as in the Western countries. In all countries (with one exception), adherence to conservative views and values of security, obedience, and respect for tradition were not important distinguishing variables. In Russia, all structural and attitudinal
\end{abstract}


differences, excluding age differentiation, were the least clear. The study shows that support for radical right-wing parties in Western Europe is socially structured and meets their ideological offer with a characteristic nationalist bias and populist rhetoric. Such a supply finds its supporters in the Eastern European countries that are members of the EU, but their views do not correspond to the socio-economic stratification of society.

Keywords: Radical right parties, voters, socio-demographics, political attitudes, nationalism, West and Eastern Europe, European Social Survey 2016 (ESS Round 8).

\section{References}

Arzheimer K. Contextual Factors and the Extreme Right Vote in Western Europe, 1980-2002, American Journal of Political Science, 2009, 53 (2), pp. 259-275.

Arzheimer K. Electoral Sociology: Who Votes for the Extreme Right and Why and When? In: The Extreme Right in Europe: Current Trends and Perspectives. Ed. by U. Backes, P. Moreau. Göttingen: Vandenhoeck and Ruprecht, 2011, pp. 35-50.

Arzheimer K., Carter E. Political Opportunity Structures and Right-Wing Extremist Party Success. European Journal of Political Research, 2006, 45 (3), pp. 419-443.

Arzheimer K. Explaining Electoral Support for the Radical Right. In: The Oxford Handbook of the Radical Right. Ed. by J. Rydgren. New York: Oxford University Press, 2018, pp. 143-165.

Bornschier S. Globalization, Cleavages, and the Radical Right. The Oxford Handbook of the Radical Right. Ed. by J. Rydgren. New York: Oxford University Press, 2018, pp. 212-238.

Bustikova L. Revenge of the Radical Right. Comparative Political Studies, 2014, 47 (12), pp. 1738-1765.

Buštíková L. The Radical Right in Eastern Europe. In: The Oxford Handbook of the Radical Right. Ed. by J. Rydgren. New York: Oxford University Press, 2018, pp. 565-581.

Coffé H. Gender and the Radical Right. The Oxford Handbook of the Radical Right. Ed. by J. Rydgren. New York: Oxford University Press, 2018, pp. 200-211.

ESS Round 8: European Social Survey Round 8 Data. Data file edition 2.1. NSD - Norwegian Centre for Research Data. Norway - Data Archive and distributor of ESS data for ESS ERIC, 2016.

ESS8. Appendix A1: Education, 2016. URL: http://www.europeansocialsurvey. org/docs/ round8/survey/ESS8_appendix_a1_e02_2.pdf (accessed: 16.03.2020).

Golder M. Far Right Parties in Europe. Annual Review of Political Science, 2016, no. 19 , pp. 477-497.

Hutcheson D.S., McAllister I. Explaining Party Support in the 2016 State Duma Election. Russian Politics, 2017, 2 (4), pp. 454-481.

Ignazi P. The Silent Counter-Revolution. Hypotheses on the Emergence of Extreme Right-Wing Parties in Europe. European Journal of Political Research, 1992, 22 (1), pp. 3-34. 
Inglehart R., Norris P. Trump, Brexit, and the Rise of Populism: Economic HaveNots and Cultural Backlash. HKS Working Paper, 2016, RWP16-026.

International Labour Office. International Standard Classification of Occupations: ISCO 08. Vol. I. Geneva: ILO, 2012. URL: http://www.ilo.org/public/english/bureau/ stat/isco/isco08/ (accessed: 16.03.2020).

Ivarsflaten E. What unites right-wing populists in Western Europe? Comparative Political Studies, 2008, 41 (1), pp. 3-23.

Kehrberg J.E. The demand side of support for radical right parties. Comparative European Politics, 2015, 13 (5), pp. 553-576.

Kitschelt H. Growth and Persistence of the Radical Right in Postindustrial Democracies: Advances and Challenges in Comparative Research. West European Politics, 2007, 30 (5), pp. 1176-1206.

Kitschelt H. Party Systems and Radical Right-Wing Parties. In: The Oxford Handbook of the Radical Right. Ed. by J. Rydgren. New York: Oxford University Press, 2018, pp. 166-199.

Kriesi H., Grande E., Dolezal M., Helbling M., Hëoglinger D., Hutter S., Wëuest B. Political Conflict in Western Europe. New York: Cambridge University Press, 2012. 368 p.

Kriesi H., Grande E., Lachat R., Dolezal M., Bornschier S., Frey T. West European Politics in the Age of Globalization. New York: Cambridge University Press, 2008. 448 p.

Lubbers M., Coenders M. Nationalistic attitudes and voting for the radical right in Europe. European Union Politics, 2017, 18 (1), pp. 98-118.

Lubbers M., Gijsberts M., Scheepers P. Extreme right-wing voting in Western Europe. European Journal of Political Research, 2002, 41 (3), pp. 345-378.

Minkenberg M. [ed.]. Transforming the Transformation? The East European radical right in the political process. London; New York: Routledge, 2015. $376 \mathrm{p}$.

Mudde C. Populist Radical Right Parties in Europe. New York: Cambridge University Press, 2007. 404 p.

Mudde C. The Study of Populist Radical Right Parties: Towards a Fourth Wave. C-REX Working Paper Series, 2016, 1.

Mudde C. Politics at the Fringes?: Eastern Europe's Populist, Racist, and Extremist. In: The Routledge Handbook of East European Politics. Ed. by A. Fagan, P. Kopecký. London: Routledge, 2017, pp. 254-263.

Muis J., Immerzeel T. Causes and Consequences of the Rise of Populist Radical Right Parties and Movements in Europe. Current Sociology Review, 2017, 65 (6), pp. 909-930.

Norris P. Radical Right: Voters and Parties in the Electoral Market. New York: Cambridge University Press, 2005. 363 p.

Norris P., Inglehart R. Cultural Backlash: Trump. Brexit. and Authoritarian Populism. New York: Cambridge University Press, 2019. 564 p.

Oesch D. Explaining Workers' Support for Right-Wing Populist Parties in Western Europe: Evidence from Austria, Belgium, France, Norway, and Switzerland. International Political Science Review, 2008, 29 (3), pp. 349-373. 
Oesch D. The Class Basis of the Cleavage between the New Left and the Radical Right: an analysis for Austria, Denmark, Norway and Switzerland. In: Class Politics and the Radical Right. Ed. by J. Rydren. London: Routledge, 2012, pp. 31-51.

Rooduijn M. What unites the voter bases of populist parties? Comparing the electorates of 15 populist parties. European Political Science Review, 2018, 10 (3), pp. 351-368.

Rydgren, J. Immigration Sceptics, Xenophobes, or Racists? Radical Right-wing Voting in Six West European Countries. European Journal of Political Research, 2008, 47 (6), pp. 737-765.

Rydgren J. The Radical Right: An Introduction. In: The Oxford Handbook of the Radical Right. Ed. by J. Rydgren. New York: Oxford University Press, 2018, pp. 1-14.

Safronov V.V. Golosovaniye za radikalnyye pravyye partii v Evrope: rol kulturnogo izmeneniya i partiynoy polyarizatsii (Chast 1) [Voting for radical right parties in Europe: the role of cultural change and party polarization (Part 1)]. Teleskop: zhurnal sotsiologicheskikh $i$ marketingovykh issledovaniy, 2018, 6, pp. 15-22. (In Russian)

Safronov V.V. Golosovaniye za radikalnyye pravyye partii v Evrope: rol kulturnogo izmeneniya i partiynoy polyarizatsii (Chast 2) [Voting for radical right parties in Europe: the role of cultural change and party polarization (Part 2)]. Teleskop: zhurnal sotsiologicheskikh i marketingovykh issledovaniy, 2019, 1, pp. 2-11. (In Russian)

Santana A., Zagórski P., Rama J. At Odds with Europe: Explaining Populist Radical Right Voting in Central and Eastern Europe. East European Politics, 2020, 36 (2), pp. 288-309.

Schwartz S.H. Universals in the content and structure of values: Theoretical advances and empirical tests in 20 countries. Advances in experimental social psychology, 1992, 25, pp. 1-65.

Schwartz S.H. A Proposal for Measuring Value Orientations across Nations. European Social Survey Core Questionnaire Development. London: European Social Survey; City University London, 2001, pp. 259-319.

Schwartz S.H. An Overview of the Schwartz Theory of Basic Values. Online Readings in Psychology and Culture, 2012, 2 (1). URL: http://dx.doi.org/10.9707/23070919.1116 (accessed: 16.03.2020).

Stockemer D., Lentz T., Mayer D. Individual Predictors of the Radical Right-Wing Vote in Europe: A Meta-Analysis of Articles in Peer-Reviewed Journals (1995-2016). Government and Opposition, 2018, 53 (3), pp. 569-593.

Werts H., Scheepers P., Lubbers M. Euro-scepticism and radical right-wing voting in Europe, 2002-2008: Social cleavages, socio-political attitudes and contextual characteristics determining voting for the radical right. European Union Politics, 2013, 14 (2), pp. 183-205. 